\title{
A CRYPTIC RECORD OF BURGESS SHALE-TYPE DIVERSITY FROM THE EARLY CAMBRIAN OF BALTICA
}

\author{
by BEN J. SLATER ${ }^{1,3}$, THOMAS H. P. HARVEY ${ }^{2}$, ROMAIN GUILBAUD ${ }^{1}$ and \\ NICHOLAS J. BUTTERFIELD ${ }^{1}$ \\ ${ }^{1}$ Department of Earth Sciences, University of Cambridge, Downing St, Cambridge CB2 3EQ, UK; benslater777@gmail.com \\ ${ }^{2}$ Department of Geology, University of Leicester, University Rd, Leicester LE1 7RH, UK \\ ${ }^{3}$ Current address: Department of Earth Sciences, Uppsala University, Villavägen 16, 752 36, Uppsala, Sweden
}

Typescript received 11 September 2016; accepted in revised form 8 November 2016

\begin{abstract}
Exceptionally preserved 'Burgess Shale-type' fossi assemblages from the Cambrian of Laurentia, South China and Australia record a diverse array of non-biomineralizing organisms. During this time, the palaeocontinent Baltica was geographically isolated from these regions, and is conspicuously lacking in terms of comparable accessible early Cambrian Lagerstätten. Here we report a diverse assemblage of small carbonaceous fossils (SCFs) from the early Cambrian (Stage 4) File Haidar Formation of southeast Sweden and surrounding areas of the Baltoscandian Basin, including exceptionally preserved remains of Burgess Shale-type metazoans and other organisms. Recovered SCFs include taxonomically resolvable ecdysozoan elements (priapulid and palaeoscolecid worms), lophotrochozoan elements (annelid chaetae and wiwaxiid sclerites), as well as 'protoconodonts', denticulate feeding structures, and a background of filamentous and spheroidal microbes. The annelids, wiwaxiids and
\end{abstract}

priapulids are the first recorded from the Cambrian of Baltica. The File Haidar SCF assemblage is broadly comparable to those recovered from Cambrian basins in Laurentia and South China, though differences at lower taxonomic levels point to possible environmental or palaeogeographical controls on taxon ranges. These data reveal a fundamentally expanded picture of early Cambrian diversity on Baltica, and provide key insights into high-latitude Cambrian faunas and patterns of SCF preservation. We establish three new taxa based on large populations of distinctive SCFs: Baltiscalida njorda gen. et sp. nov. (a priapulid), Baltichaeta jormunganda gen. et sp. nov. (an annelid) and Baltinema rana gen. et sp. nov. (a filamentous problematicum).

Key words: Cambrian explosion, small carbonaceous fossils, Burgess Shale-type preservation, priapulids, Wiwaxia, annelids.
Lower Cambrian sediments of Sweden have long been known to contain a variety of shelly macrofossils (Ahmman \& Martinsson 1965; Bergström 1968; Topper \& Skovsted 2014), small shelly fossils (SSFs) (Bengtson 1968), ichnofossils (Linnarsson 1871; Jensen 1990, 1997; Jensen \& Bergström 2000) and acritarchs (Vidal 1981; Hagenfeldt 1989, 1994; Eklund 1990; Hagenfeldt \& Bjerkéus 1991). Body fossils of non-biomineralizing organisms, however, are limited to a handful of isolated euarthropods and lobopodians (Størmer 1956; Bergström 1971; Krumbiegel et al. 1980; Dzik \& Krumbiegel 1989), with no evidence of the diverse Burgess Shale-type (BST) macrofossil assemblages that have revolutionized our understanding of early Cambrian palaeobiology in Laurentia, South China and Australia (Butterfield 2003). The only documented occurrence of Cambrian macroscopic BST preservation currently recorded from Baltica is three specimens from a deep drillcore of the Zawiszyn Formation, Poland (Lendzion 1975; Dzik \& Lendzion 1988; Daley \& Legg 2015).

There is, however, an alternative means of capturing a measure of BST diversity, even in the absence of exceptional macrofossil preservation. The (mostly) disarticulated, taphonomically recalcitrant elements of these organisms are widely recovered as 'small carbonaceous fossils' or SCFs (Butterfield \& Harvey 2012). Like their 'small shelly' counterparts, SCFs are deeply polyphyletic, united by little more than their size and a particular search image, in this case organic-walled fossils that are too small to be seen on bedding surfaces, but too large or delicate to be reliably recovered via conventional palynological processing. Despite their fragmentary nature, however, many SCFs can nonetheless be resolved to a taxonomically informative level. Importantly, what SCFs 
lose from disarticulation they gain in abundance and distribution, offering a fundamentally enhanced account of palaeobiogeographical and stratigraphical patterns. The key to recovering these large-scale patterns, of course, is global sampling, though most Cambrian SCF studies to date have been centred on relatively few localities in western Canada and South China (Butterfield 1994; Butterfield \& Harvey 2012; Harvey et al. 2012a, b; but see Smith et al. 2015a). Here we expand this record to the palaeogeographically isolated palaeocontinent of Baltica.

Global palaeogeographical reconstructions of the early Cambrian vary considerably (e.g. McKerrow et al. 1992; Li et al. 2008; Meert \& Lieberman 2008), but there is general agreement that the sedimentary depocentres of Scandinavia/Baltoscandia and the East European Platform belonged to a coherent craton, Baltica, separated from other contemporary landmasses by substantial expanses of ocean (Torsvik \& Cocks 2005; Cawood \& Pisarevsky 2006; Meert 2014). During the early Cambrian, presentday Scandinavia lay in an inverted position, facing the South Pole (Hartz \& Torsvik 2002; Cocks \& Torsvik 2005; Álvaro et al. 2016). Although once thought to oppose Laurentia across the Iapetus Ocean (see Hartz \& Torsvik 2002, fig. 1), the Scandinavian margin is now considered to have faced Siberia on the margins of the Ægir Ocean (Nielsen \& Schovsbo 2011). Moreover, almost all palaeomagnetic data place Baltica in the mid to high temperate palaeolatitudes $\left(35-60^{\circ} \mathrm{S}\right)$ during the early Cambrian (Torsvik \& Rehnström 2001; Meert \& Lieberman 2004; Cocks \& Torsvik 2005; Landing et al. 2013). By contrast, all of the well-known Cambrian BSTLagerstätten fall within the palaeotropics.

\section{GEOLOGICAL SETTING}

The File Haidar Formation (early Cambrian, Stage 4) is locally exposed at the surface in and around southern Sweden, and subcrops extensively beneath the Baltic Sea (Figs 1, 2; Hagenfeldt 1989, 1994; Nielsen \& Schovsbo 2007). Deposition took place in a shallow epicontinental sea, broadly mirroring the architecture of the modern Baltic and Bothnian seas, and separated from the Russian margin by a substantial hinterland (Flodén 1980; LidmarBergström 1988; Nielsen \& Schovsbo 2011, figs 82-86).

The File Haidar Formation consists of fine-medium sandstones interspersed with recurrent mudstones and siltstones, overlying a weathered gneissic basement (Holm 1901). Across much of its extent, the File Haidar Formation is terminated by a regional unconformity corresponding to the 'Hawke Bay event' (Fig. 2; see Nielsen \& Schovsbo 2015) and is overlain by the predominantly middle Cambrian (Stage 5) Borgholm Formation (Nielsen \& Schovsbo 2007). In places, however, this latter contact is gradational, and parts of the Borgholm Formation (e.g. the Grötlingbo Member) are recognized as latest early Cambrian in age, with the diachronous boundary younging westwards (Nielsen \& Schovsbo 2011). The subsurface portions of the File Haidar Formation are well known from drillcore, and have been extensively studied both sedimentologically (e.g. Nielsen \& Schovsbo 2007, 2011) and for acritarch biostratigraphy (Hagenfeldt 1989, 1994; Eklund 1990).

The early Cambrian age (Stage 4; c. 514-509 Ma) of the File Haidar Formation, used here following the scheme of Nielsen \& Schovsbo (2011), is based on a combination of acritarch biostratigraphy (Heliosphaeridium dissimilare - Skiagia cilosa, Volkovia dentifera - Liepaina plana assemblage zones (Hagenfeldt 1989, 1994; Moczydłowska \& Vidal 1986; Moczydłowska 1991, 1998)) and detailed sequence-stratigraphical correlation (Nielsen \& Schovsbo 2007, 2011) to the Holmia kjerulfi and 'Ornamentaspis' linnarssoni trilobite zones (Bergström \& Ahlberg 1981; Ahlberg \& Bergström 1993). Shelly fossils are rare in the File Haidar Formation, confined to occasional fragmentary trilobite remains (Ahlberg 1984; Ahlberg et al. 1986) and rare brachiopods, though some surface exposures yield abundant SSFs including Mobergella (Åhman \& Martinsson 1965); trace fossils typical of early Cambrian assemblages are also locally abundant (Jensen 1997). The underlying crystalline basement is substantially older, with bounding age constraints of 1700 and $900 \mathrm{Ma}$ (Welin et al. 1982).

Sediments of the File Haidar Formation record marine deposition in a storm-influenced nearshore sand belt. Proximal environments are sand-dominated, with distal regions of the inner-shelf grading into siltstones and shales (Nielsen \& Schovsbo 2007). The formation is subdivided into five members based on lithology and thin conglomeratic marker beds (Figs 2, 3; Nielsen \& Schovsbo 2007, 2011). Sediments of the lowermost Viklau Member consist of interbedded green-grey quartz sandstones, bioturbated siltstones and green shales. The overlying När Shale Member is dominated by quartz sandstone in proximal settings (e.g. in the File Haidar-1 core; Fig. 3), grading distally into successions of heavily bioturbated green-grey siltstones and shales with subordinate sandstones (e.g. in the Grötlingbo-1 core; Fig. 3). The När Sandstone Member is dominated by fine-medium grained quartz sandstones with occasional subordinate siltstone beds. The proximal equivalents of these three members are the Mickwitzia Sandstone and overlying Lingulid Sandstone members; both of these are extensively bioturbated, though the Mickwitzia is more thinly bedded, contains numerous clay horizons, and preserves a substantially greater diversity of ichnotaxa, including both hunting and priapulid-like trace fossils (Bergström 1973; Jensen 1990, 1997; Jensen \& Bergström 1995; Rydell et al. 2001). 
FIG. 1. Map showing distribution of sampled drill-cores intersecting the File Haidar Formation. Abbreviations: Gr-1, Grötlingbo-1; FH-1, File Haidar-1; Ha-1, Hamnudden-1; BH, Böda Hamn; Bå-2, Bårstad-2; Be-2, Bernstorp-2; Fi, Finngrundet. Preserved extent of File Haidar Formation shown in dark grey.

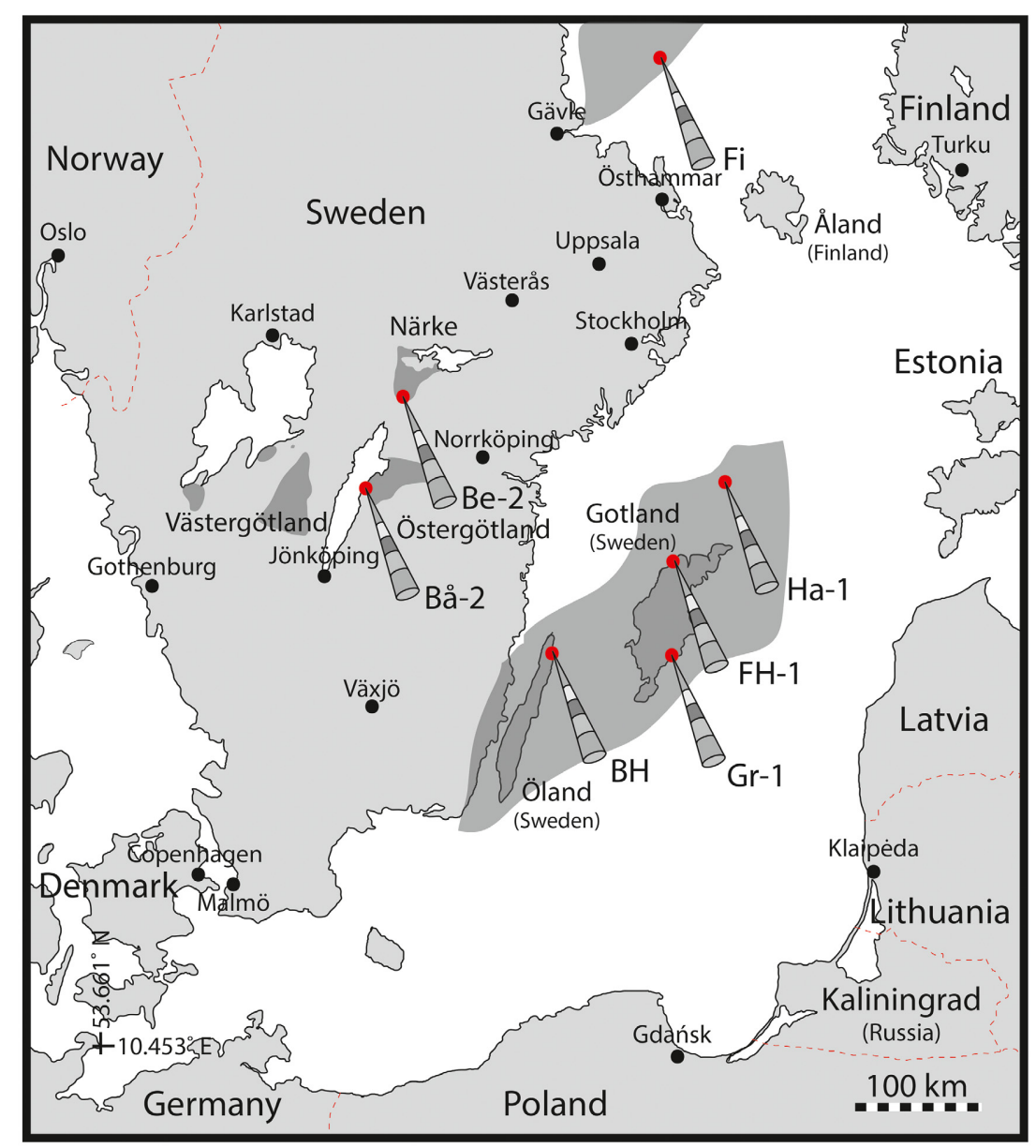

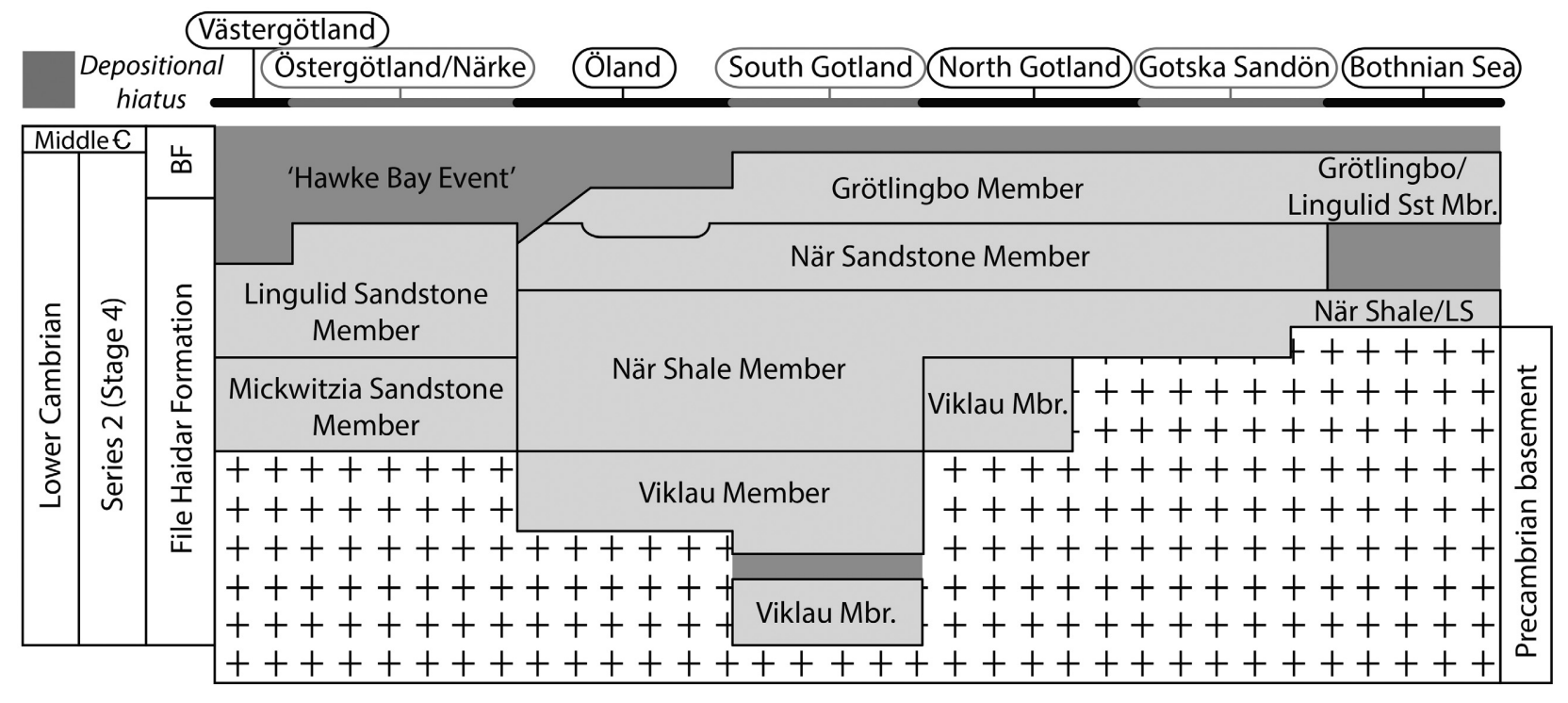

FIG. 2. Subdivisions (members) and occurrence of the File Haidar Formation across southern Sweden and the Bothnian Sea (after Nielsen \& Schovsbo 2011, fig. 7). Abbreviations: BF, Borgholm Formation; LS, Lingulid Sandstone Member.

The Viklau, När Shale and När Sandstone members are all substantially developed in subsurface drillcores around Öland and Gotland (Thorslund \& Westergård 1938;
Hessland 1955); the Viklau Member is absent in the southern Bothnian Sea, however, where the Cambrian succession begins with the När Shale (Fig. 2). Significant 
surface exposures of these members include the distinctively red-striated and well-cemented Kalmarsund sandstone, which crops out on the southwest coast of mainland Sweden and is now interpreted as diagenetically altered Viklau, När Shale and När Sandstone strata (Nielsen \& Schovsbo 2007). Further inland, the Mickwitzia Sandstone and Lingulid Sandstone members are locally exposed at the surface around Västergötland, Östergötland and Närke, where they are also known from drillcore material (Figs 1, 2).

\section{MATERIAL AND METHOD}

The File Haidar Formation was sampled from seven widely separated drillcores in and around southern Sweden (Figs 1, 3); Grötlingbo-1 (Gr-1), File Haidar-1 (FH1), Hammnudden-1 (Ha-1), Böda Hamn (BH), Bårstad-2 (Bå-2), Bernstorp-2 (Be-2) and Finngrundet (Fi). All cores are housed in the drillcore repository of the Geological Survey of Sweden at Eggebyholm, near Knivsta, Uppland, Sweden. Our sampling protocol included all unoxidized mudstones, siltstones and sandstones, apart from pure quartz arenites. At least one sample was collected per metre of suitable lithology, yielding a total of 217 samples representing all five of the constituent members (Fig. 3). Approximately $50 \mathrm{~g}$ of each sample was digested and processed for SCFs using a low-manipulation hydrofluoric acid maceration procedure, and resultant organic residues were hand-picked for SCFs (see Butterfield \& Harvey 2012).

\section{SMALL CARBONACEOUS FOSSILS}

A total of 3613 SCFs were mounted onto 261 slides from 66 productive samples. Although all seven boreholes yielded fossils, samples from Gr-1, FH-1, BH-1 and Bå-2 were by far the most abundant and diverse, with fissile siltstones and fine-grained glauconitic sandstones producing the bulk of specimens (Fig. 3). Most of the recovered SCFs are recognizably metazoan/bilaterian and can be classified as having either ecdysozoan or lophotrochozoan affiliations; phylogenetically less resolved forms are assigned to 'unresolved metazoans' or 'non-metazoan problematica'.

\section{Ecdysozoa}

The protostome superphylum Ecdysozoa includes both the Panarthropoda (euarthropods, onychophorans and tardigrades) and Cycloneuralia (scalidophorans and nematoids), all of which are characterized by a variably tanned/sclerotized cuticle periodically shed through ecdysis. The inherent recalcitrance of this extracellular material, combined with a propensity for body parts to disarticulate along lines of cuticular jointing or thinning, means that ecdysozoans are particularly conducive to the production of SCFs. Arthropods are by far the most abundant and diverse ecdysozoans today, and dominate a number of Cambrian SCF assemblages (e.g. Harvey et al. 2012b). Scalidophoran worms (represented by modern priapulids, kinorhynchs and loriciferans) were also a significant component of Cambrian ecosystems, represented by trace fossils, Burgess Shale-type macrofossils and, increasingly, SCF assemblages (Harvey et al. 2012a; Butterfield \& Harvey 2012; Smith et al. 2015b); we expand upon this record here.

Priapulid-like scalids, teeth and hooks. Sub-triangular, thick-walled elements bearing denticles, projections and/ or polygonal surface micro-ornament are locally abundant in parts of the Viklau and När Shale Members of the Gr1 and FH-1 cores (Figs 3, 4, 5A-Q). Considerable variation is evident among the recovered specimens, but all conform to the same basic architecture, consisting of a prominent conical 'prong' at the distal tip of a thickened chevron-shaped 'arch' which caps an ovoid 'basal pad' (Fig. 4A; Smith et al. 2015b) though the thinner-walled basal pad has been secondarily lost from all but a few specimens (e.g. Fig. 5B). In most specimens the arch is fringed by an array of smaller conical 'denticles' which flare at the base and taper to an acute point (Fig. 5A-Q). Beyond this basic architecture, the specimens exhibit a considerable range of outlines and marginal ornamentations, forming a broad continuum encompassing three apparent end-members or 'types'. Type 1 specimens exhibit an elongate triangular outline with small, closelyspaced marginal denticles distributed along most of the length of the arch/prong complex (e.g. Fig. 5F, H). Type 2 specimens bear fewer, more robust denticles that increase in size towards the central prong, and have a broader, more equidimensional outline (e.g. Fig. 5A). Type 3 specimens are more elongate with an acute-angled arch that tapers to a pronounced prong, and exhibit a significant gap between the most distal denticles and the tip of the central prong (e.g. Fig. 5B-E, G). The denticles in type 3 specimens are sometimes branched at their tips (e.g. Fig. 5O, Q) and are frequently arranged in an asymmetrical pattern on either margin of the arch; in contrast to type 2 specimens, there is no clear size trend among the denticles (e.g. Fig. 5B).

Taken together, these denticulate File Haidar SCFs are reliably interpreted as the dispersed cuticular remains of priapulid-like scalidophoran worms. 'Sclerites' of the same fundamental construction to those found in the Gr-1 and FH-1 cores are found in a variety of modern 


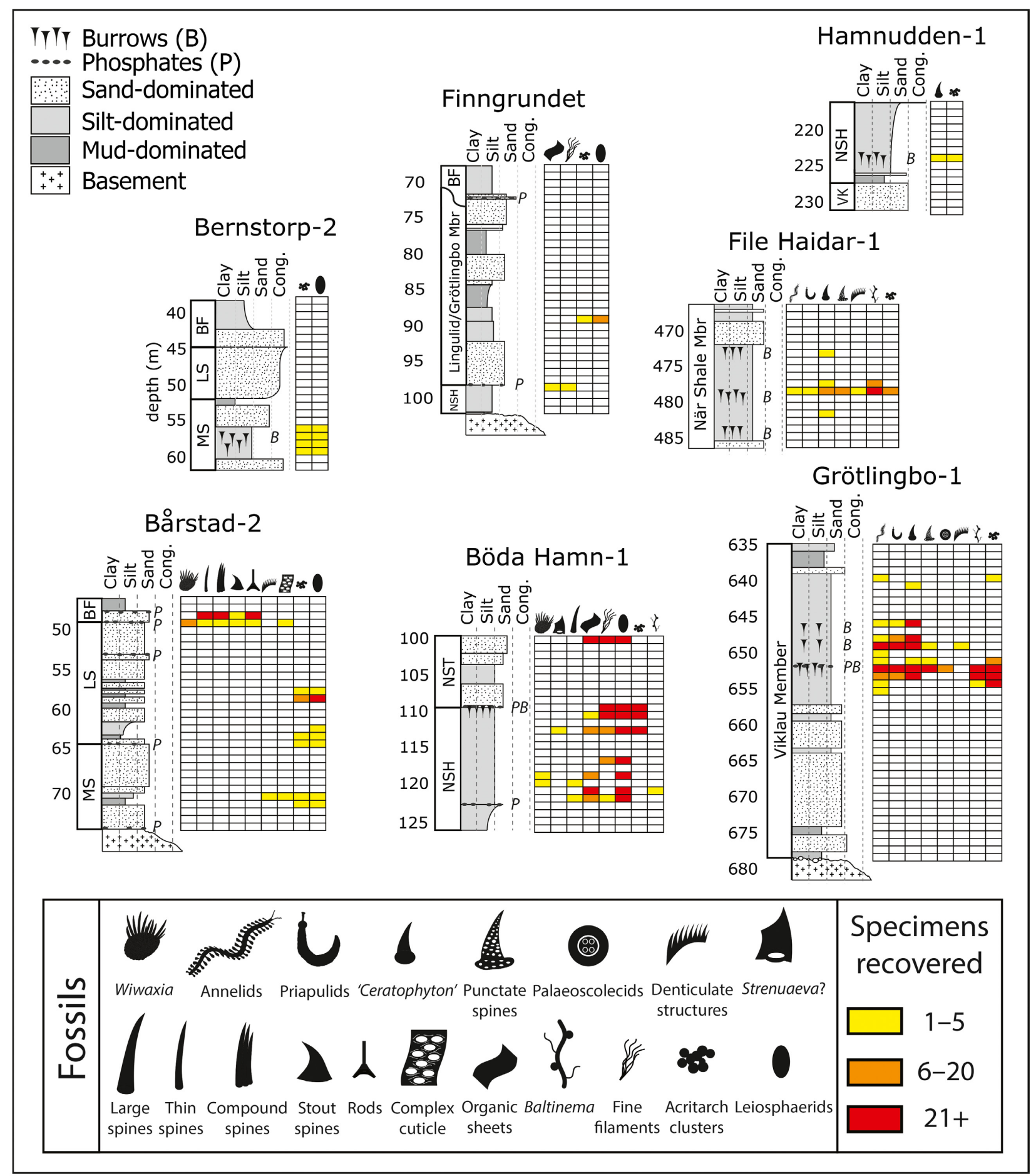

FIG. 3. Stratigraphical distribution of SCFs recovered from core material intersecting the File Haidar Formation. Sedimentary logs after Nielsen \& Schovsbo 2011 and personal observations. Abbreviations: BF, Borgholm Formation; LS, Lingulid Sandstone Member; MS, Mickwitzia Sandstone Member; NST, När Sandstone Member; NSH, När Shale Member; VK, Viklau Member. Number of samples: Ha-1, 11; Be-2, 9; Fi, 39; FH-1, 8; Bå-2, 33; BH-1, 56; Gr-1, 51. For location of cores see Fig. 1.

priapulids (e.g. van der Land 1970; Wennberg et al. 2009), as well as Cambrian stem-priapulids such as Ottoia and the tubicolous genus Selkirkia (Smith et al. 2015b); they are also abundant in many previously-described SCF assemblages (Butterfield \& Harvey 2012; Harvey et al. $2012 a, b)$. In particular, it is the approximately bilaterally 
A

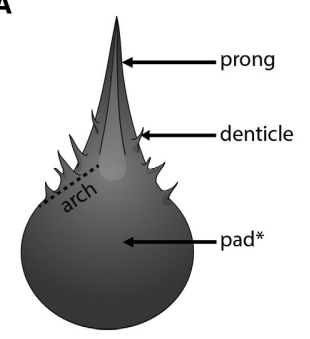

B

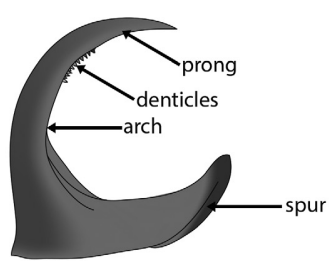

C

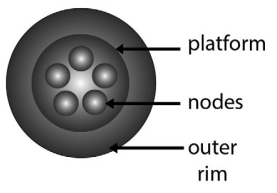

G

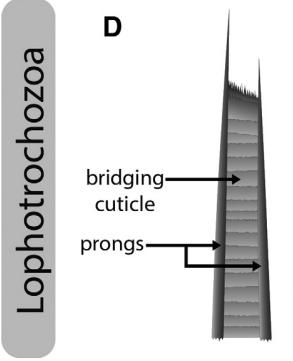

E

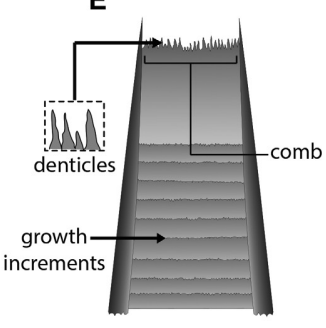

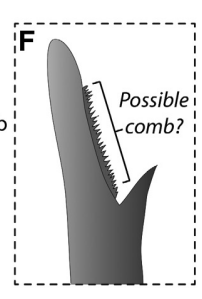

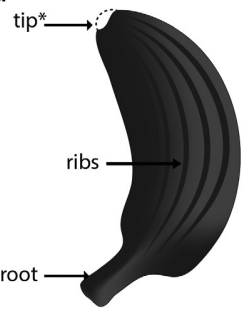

FIG. 4. Schematic guide to File Haidar SCF terminology. A-B, priapulid teeth and scalids. C, palaeoscolecid plates. D-F, annelid chaetae: D, E, Baltichaeta jormunganda showing morphological end members; F, distal tip of Burgessochaeta setigera chaeta for comparison. G, wiwaxiid sclerite (ventrolateral sclerite). ${ }^{*}$ indicates usually damaged or missing in recovered specimens. symmetrical outline combined with a flattened-oval or triangular basal attachment shape that distinguishes these priapulid-type sclerites from simpler, less phylogenetically informative conical structures and from annelid scolecodonts (see discussions in Smith et al. 2015b, p. 713; Eriksson et al. 2016); the absence of an inner groove, strongly developed ridges (rugae), or fine parallel growth lines rules out comparisons with superficially similar machaeridian annelid plates (e.g. Adrain et al. 1991, figs 1,2$)$. In modern priapulids, spinose cuticular projections of the anterior body regions are termed 'scalids' when they occur on the introvert or trunk, whereas 'teeth' are positioned on the pharynx and point forward when everted (van der Land 1970), a distinction that is usefully applied to various fossil scalidophorans (Harvey et al. 2012a; Smith et al. 2015b). The specimens in Fig. 5A-Q are likely to be 'teeth' based on their outline shapes and prominent fringing spines, whereas scalids tend to be more elongate and are often unadorned, or have spines in rows closer to the midline, rather than marginally (Smith et al. 2015b).

The type 2 teeth described here are broadly comparable to the type B teeth in Ottoia prolifica (cf. Smith et al. $2015 b$, fig. 3) unlike the more elongate outlines of the type 1 and type 3 specimens. Even so, the prong is substantially less clearly differentiated from the supporting arch than in Ottoia, and none of the particular morphologies in the File Haidar has been previously documented, either from BST macrofossils or among priapulid-like SCFs. Type 1 and type 3 specimens are also distinct from other known priapulid teeth, but given the consistent co-occurrence of all three tooth types in our samples, as well as the tooth zonation patterns known from pharyngeal apparatuses of extant and articulated macrofossil priapulids (cf. Schmidt-Rhaesa 2013, fig. 4.1.8 A; Smith et al. 2015b), the File Haidar teeth are likely to be of a conspecific origin. At the same time, we consider the File Haidar tooth morphologies sufficiently distinct from those of any previously described priapulid to warrant the establishment of a new taxon, Baltiscalida njorda gen. et. sp. nov. (see Systematic Palaeontology below).

The File Haidar samples that preserve priapulid teeth also yield recurved hooks with a pronounced 'spur' (Figs 4B, 6). Broadly comparable forms have been reported from a number of SCF assemblages from Canada and South China (Butterfield 2008; Butterfield \& Harvey 2012; Harvey et al. 2012a; Smith et al. 2015b), though these latter occurrences are typically distinguished by serially arranged denticles or fine projections along the inner curve of the hook (see Butterfield 2008, fig. 6); such elaboration is absent from all but one of the File Haidar examples (Fig. 6X). Because these hook-like SCFs consistently co-occur in samples with types 1, 2 and 3 priapulid teeth, and exhibit a morphological range consistent with the variation seen within individual fossil worms (cf. Smith et al. 2015b), we interpret them as scalid elements conspecific with Baltiscalida njorda gen. et. sp. nov. (see Systematic Palaeontology below).

Palaeoscolecids. Small $(\sim 40-100 \mu \mathrm{m}$ diameter $)$ discoidal elements occur locally in the Viklau Member of the GB-1 core (Fig. 5R-V). These plate-like SCFs have a thin outer rim, and a darker, thicker central region that bears between three and five protuberances or 'nodes'. Mineralized (phosphatic) plates of this size and form are 


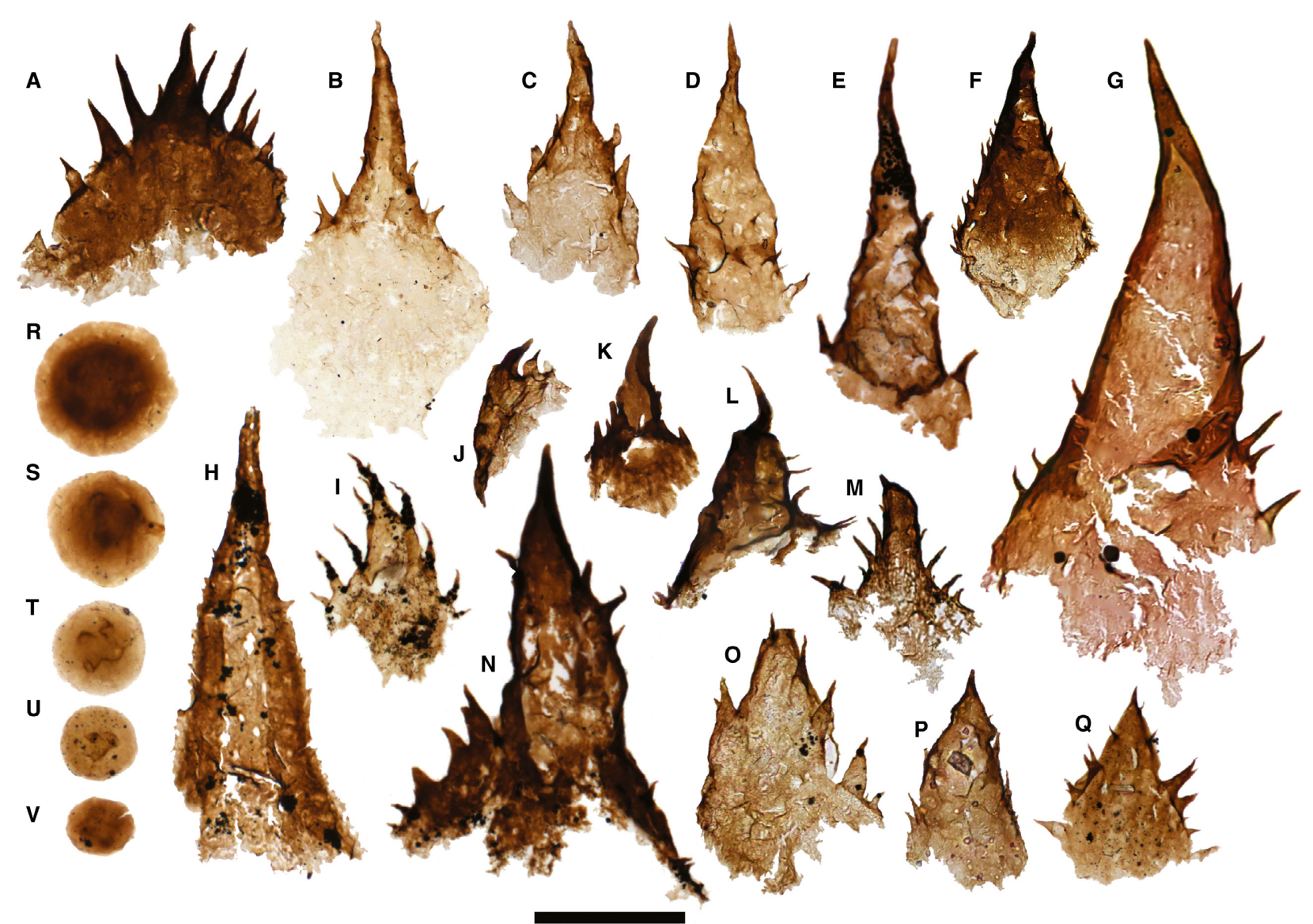

FIG. 5. Priapulid teeth $(\mathrm{A}-\mathrm{Q})$ and palaeoscolecid plates $(\mathrm{R}-\mathrm{V})$ recovered from the Viklau and När Shale Members of the File Haidar Formation. A, type 2 tooth. B, type 3 tooth, holotype of Baltiscalida njorda gen. et sp. nov (England-finder co-ordinates; N.50-3). C-E, type 3 teeth. F, type 1 tooth. G, large type 3 tooth. H, type 1 tooth. I, type 2 tooth. J-Q, type 3 teeth, smaller forms displaying an intermediate morphology between types 2 and 3. R-V, Hadimopanella. All slide numbers have the prefix NRM PZ X: A, C, P, 6150; B, F, 6152; D, K, 6156; E, 6184; G, 6176; H, 6166; I, N, 6190; J, 6148; L, 6175; M, 6185; O, 6160; Q, 6188; R, 6219; S, 6214; T-V, 6216. Sample depths from Gr-1 core: A, C, J, P, 648.94 m; B, D, F, K, 648.99 m; H, O, 651.07 m; E, I, M, N, Q, 651.00 m; G, L, 651.64 m; R, $563.60 \mathrm{~m}$; S, $647.75 \mathrm{~m}$; T-V, $565.80 \mathrm{~m}$. Scale bar represents $100 \mu \mathrm{m}$.

conventionally assigned to the form-genus Hadimopanella which occurs widely in Cambrian assemblages of SSFs. Though originally described from isolated sclerites, Hadimopanella-type plates are now known to have adorned the surface of palaeoscolecids, an extinct group of early Palaeozoic worms with an annulated armoured trunk, a retractile introvert and tail hooks (Hinz et al. 1990), now recognized as stem-priapulids (Harvey et al. 2010; Wills et al. 2012). Because the morphology and distribution of Hadimopanella-type plates varies substantially within individuals (e.g. Ivantsov \& Wrona 2004; Topper et al. 2010; Streng et al. 2016), isolated plates cannot usually be used to identify a particular taxon (see discussions in GarcíaBellido et al. 2013; Smith 2015).

Along with a preliminary report from the Furongian of western Canada (Butterfield \& Harvey 2012), the identification of Hadimopanella-type sclerites from siliciclastic sediments of the File Haidar Formation substantially expands the known biogeographical and taphonomical ranges of a prominent group of early Palaeozoic worms. Both occurrences are most parsimoniously interpreted as the taphonomically demineralized remains of an originally phosphatic form, though it is possible that they represent a distinct non-biomineralizing habit (see Butterfield \& Nicholas 1996; Harvey 2010).

Cuticular 'spines'. Alongside the distinctively scalidophoran-type teeth, hooks and cuticular plates, the File Haidar assemblage preserves a diversity of more simple coniform and spinose SCFs. The most common of these are stout, conical spines with a flared, elliptical to circular base (Figs 3, 7A-H, N-R). Other forms include thickerwalled spines (presumably reflecting a more heavily sclerotized composition in life) (Fig. 7S-U), and broader, 


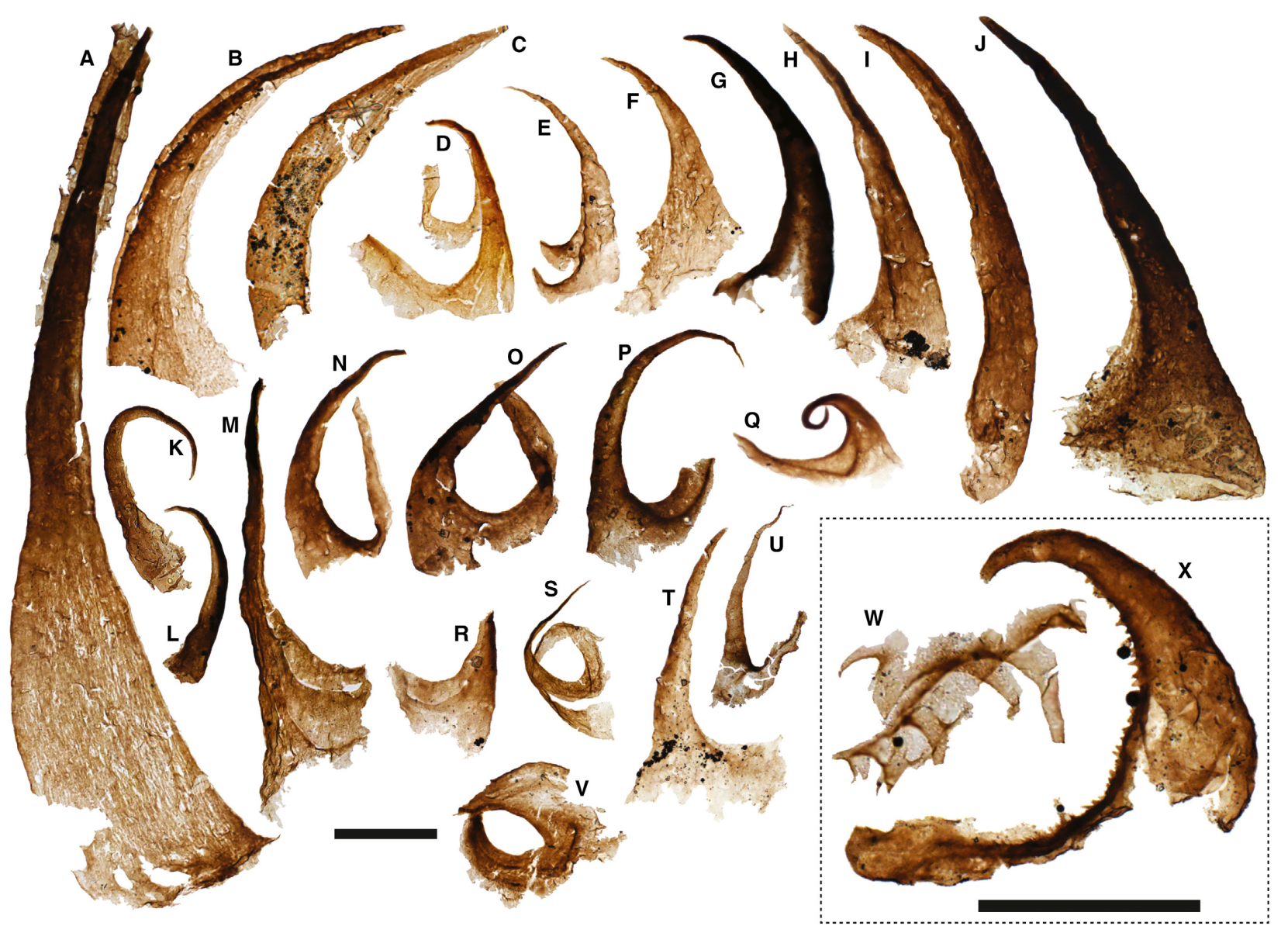

FIG. 6. Scalids representing a mixture of tail and introvert hooks derived from stem priapulids. A-V, variety of scalids lacking any evident denticles; distal curling of some specimens (e.g. Q) is probably a taphonomic feature. W, cluster of scalids with extended portion of cuticle. X, probable introvert hook bearing short denticles along the arch. All slide numbers have the prefix NRM PZ X: A, 6197; B, 6169; C, 6234; D, 6238; E, F, 6154; G, 6188; H, R, 6155; I, N, 6156; J, L, S, 6192; K, 6152; M, 6193; O, T, 6153; P, 6177; Q, V, 6221; U, 6200; W, 6149; X, 6157. Sample depths from FH-1 core: D, 479.00 m; C, 479.05 m. Sample depths from Gr-1 core: A, J, L, M, S, 651.10 m; B, 651.59 m; E, F, H, I, K, N, O, R, T, X, 648.99 m; G, 651.00 m; P, 652.23 m; Q, V, 646.25 m; U, 653.00 m; W, $648.94 \mathrm{~m}$. Both scale bars represent $100 \mu \mathrm{m}$.

often much larger (up to $600 \mu \mathrm{m}$ ) coniform specimens with a densely perforated construction (Fig. 7I-M). Both of these latter forms are represented by occasional specimens with reticulate or polygonal basal extensions (Fig. 7K-L, S, U), presumably the remains of a contiguous external cuticle.

A significant subset of the shorter, thinner-walled File Haidar spines (Fig. 7A-H, N-R) are indistinguishable from microfossils that have been assigned to the 'acritarch' form-taxon Ceratophyton (Kiryanov 1979 in Volkova et al. 1979; Hagenfeldt 1989, 1994; Wright et al. 1993; Konzalová 1995; Jachowicz \& Moryc 1995; Zang et al. 2007; Palacios et al. 2011). Despite this implied protistan-grade affiliation, however, there is a strong case for recognizing such SCFs as metazoan (Steiner \& Fatka 1996; Moczydłowska 2008; Agić et al. 2016), and, more specifically, scalidophoran in origin (Butterfield \& Harvey 2012; Smith et al. 2015b). Specimens with ovoid bases and the long axis of the cone oblique to the basal attachment, for example, or a polygonal micro-ornamentation of the basal cuticle, share these features with more complex and definitively priapulid-like scalids and teeth (cf. Smith et al. 2015b). Moreover, several of the File Haidar 'Ceratophyton' exhibit basal extensions suggesting they were once attached to a larger cuticular sheet (e.g. Fig. 7C, N), and a few specimens are preserved in articulation with other spines (Fig. 7D). Indeed, many of the spinose SCFs in the File Haidar could represent simple conical priapulid-like scalids of the sort borne on the embryonic/juvenile Cambrian scalidophorans Markuelia and Eopriapulites (see Dong et al. 2005, fig. 2; Liu et al. 2014; Shao et al. 2016). 


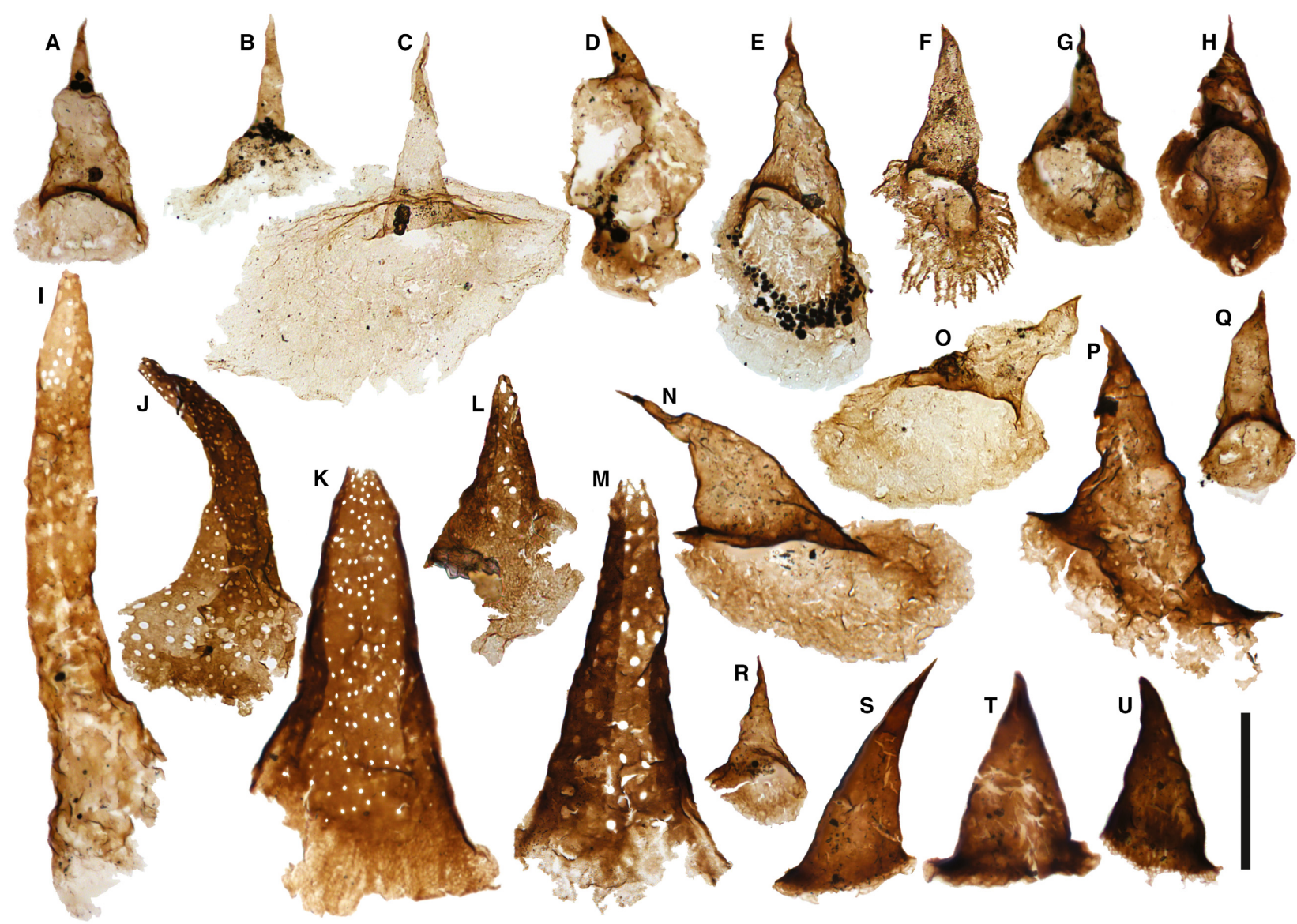

FIG. 7. Cuticular spines, probably derived from scalidophoran 'worms'. A-H, N-R, simple stout spines with a flared, roughly circular base ('Ceratophyton'-type spines); B-F, N-P, display attachment to extended sheets; D, two spines with extended basal sheets in attachment, the distal tip of the lower spine has been flattened. S-U, heavily sclerotized spines with reticulate basal architecture. I-M, perforated spines; K, L, display basal extension with reticulate structure reminiscent of scalidophoran cuticle. All slide numbers have the prefix NRM PZ X: A, C, 6194; B, D, H, U, 6184; E, 6175; F, 6186; G, 6190; I, K, S, T, 6221; J, 6193; L, 6148; M, 6153; N, 6164; O, 6204; P, 6166; Q, 6189; R, 6197. Sample depths from Gr-1 core: A, C, J, R, 651.10 m; B, D, F-H, Q, U, 651.00 m; E, 651.64 m; I, K, S, T, 646.25 m; L, 648.94 m; N, P, 651.07 m; M, 648.99 m; O, 653.00 m. Scale bar represents $100 \mu \mathrm{m}$.

\section{Lophotrochozoa}

The other major protostome clade, the Lophotrochozoa, includes a wide range of palaeontologically important groups, including molluscs, annelids, brachiopods and bryozoans. Various lophotrochozoans possess a nonmineralizing but potentially preservable integument, although inherently recalcitrant components are typically limited to mouthparts and preferentially tanned chaetae (Butterfield 1990a). Chaetae (or chaetal homologues) are found among a disparate range of lophotrochozoan clades including annelids, brachiopods, and certain bryozoans and molluscs, collectively pointing to a deep lophotrochozoan symplesiomorphy (Butterfield 2006, 2008; Dunn et al. 2008; Giribet et al. 2009; Struck et al. 2011; Topper et al. 2015; Tilic et al. 2015a, b). All lophotrochozoan 'chaetae' are microvilli-secreted via basal addition, imparting a distinctive microstructure of longitudinally arranged parallel internal channels (Schroeder 1984; Butterfield 1990b; Purschke 2002; Hausen 2005). In combination with external morphology, this characteristic microstructure allows a significant subset of SCFs to be assigned to this super-phylum.

Annelid chaetae. Strap-shaped SCFs with distinctively bifid tips (Fig. 8) are particularly common in parts of the Viklau and När Shale Members (GB-1 and FH-1 cores; Fig. 3). Most occur as isolated shafts but one semi-articulated specimen is represented by five constituent elements (Fig. 8B, Z). Individual specimens are $\sim 35-210 \mu \mathrm{m}$ wide with a maximum (incomplete) length in excess of a millimetre. Preserved tips consist of a pair of lateral prongs (thickened longitudinal margins) with thinner material in between forming a comb-like series of serrations 

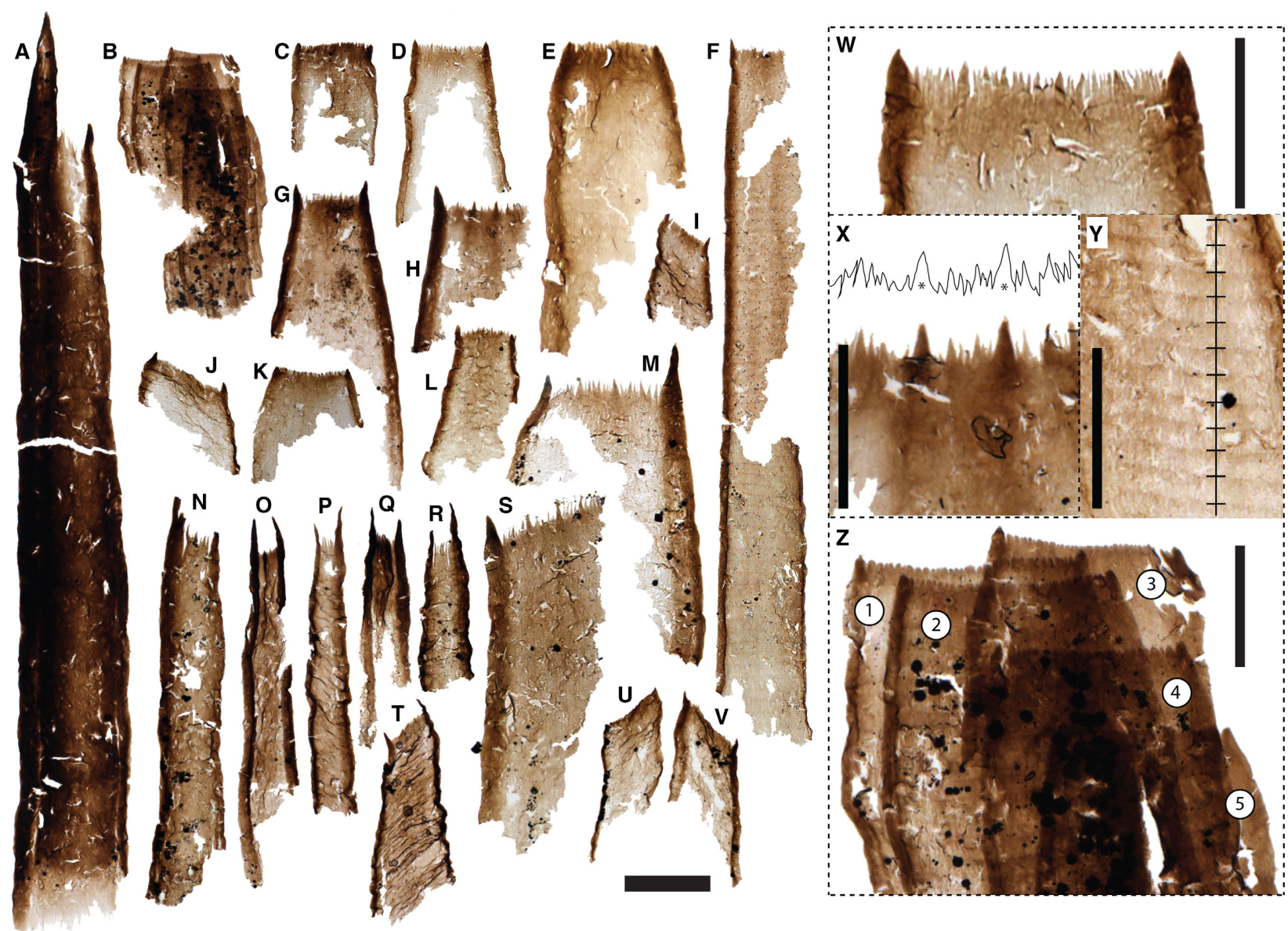

FIG. 8. Chaetae of Baltichaeta jormunganda gen. et sp. nov. A, holotype specimen (England-finder co-ordinates; L.49-4). B, cluster of five chaetae of the squatter morphology. W, close-up of D, showing brush-tip. X, close-up of H, showing serrations of brush-tip, including two prominent serrations marked * in corresponding line-drawing. Y, equally spaced increments developed inside chaetae. $Z$, close-up of clustered specimen B, derived from a partially preserved chaetiger, individual chaetae marked 1-5. All slide numbers have the prefix NRM PZ X: A, O, Y, 6154; B, P, Z, 6156; C, 6152; D, W, 6197; E, 6191; F, 6153; G, L, U, V, 6190; H, I, T, X, 6155; J, R, 6193; K, 6192; M, 6176; N, S, 6198; Q, 6157. Sample depths from Gr-1 core: A-C, F, H, I, O-Q, T, X, Y, Z, 648.99 m; D, E, J, K, R, W, 651.10 m; G, L, U, V, 651.00 m; N, S, 651.50 m; M, 651.64 m. Scale bars represent: $100 \mu \mathrm{m}(\mathrm{A}-\mathrm{V}) ; 50 \mu \mathrm{m}(\mathrm{W}-\mathrm{Z})$.

(Figs $4 \mathrm{D}-\mathrm{E}, 8 \mathrm{~W}$ ). The prongs always extend beyond the intervening serrations, though they vary considerably in size both within and between individual specimens. Individual serrations of the comb either taper to a point (e.g. Fig. $8 \mathrm{X}$ ) or are somewhat rounded (e.g. Fig. 8Z), the latter type typical of specimens with more symmetrical termini and shorter serrations of consistent dimensions. As a population, the distal morphology varies along a continuum between two co-occurring end-members, one in which asymmetrical prongs project well beyond the comb tip (e.g. Fig. 8A), and the other with proportionately broader, shorter prongs of approximately equal length (e.g. Fig. 8B-E); the latter form has substantially wider combs and often exhibits two hyper-developed serrations that divide the comb approximately into thirds (Fig. 8X). Other features of these strap-shaped fossils include a pattern of regularly spaced transverse ridges with a $\sim 5-$ $12 \mu \mathrm{m}$ interval (Fig. 8Y), and, in well-preserved specimens, an internal microstructure of densely packed, $<1 \mu \mathrm{m}$ non-overlapping striations (Fig. 8W-Y) directly comparable to that of microvilli-secreted chaetal structures.

The combination of microvilli-like microstructure, complex tip morphology and bundled occurrence seen in these SCFs is directly comparable to that of annelid chaetae (cf. Hausen 2005; Merz \& Woodin 2006; Tilic et al. 2015a). In particular, close morphological comparisons can be made with the 'brush-chaetae' of certain 'polychaete' annelids (Mettam 1971, 1984; Roy 1974; KnightJones 1981; Rouse \& Pleijel 2001). The characteristically complex-tipped chaetae of annelids, particularly marine polychaetes, contrast with the simple spines or rods 
secreted by other groups, for example brachiopod setae or bryozoan teeth (cf. Gordon 1975; Zhang et al. 2007; Zhang \& Holmer 2013; Topper et al. 2015). Additional support for an annelidan affinity comes from the cluster of five superimposed elements, which we interpret as a fragmentary portion of a single polychaete chaetiger - a fan of chaetae borne on the lateral margins of a body segment (Fig. 8B, Z).

The chaetae of modern annelids exhibit an enormous diversity of form, which at the broadest scale fall into two categories: simple or compound, with the latter characterized by an internally jointed articulation and/or dentate terminal hooks. Like all other known Cambrian annelid chaetae (see Parry et al. 2014, 2016), the File Haidar specimens are simple; the transverse ridges (Fig. $8 \mathrm{Y}$ ) in the File Haidar specimens are likely to be growth ridges acquired as the plastic chaetal material hardened incrementally within the chaetoblast (cf. O'Clair \& Cloney 1974), rather than differentiated articulations. Among modern annelid groups, chaetal morphologies that are at least broadly similar to those of the File Haidar SCFs are found among the Eunicidae (Rouse \& Pleijel 2001), but also some enigmatic terrestrial non-oligochaete annelids (cf. Pižl \& Chalupský 1984; Rota \& Lupetti 1996; DózsaFarkas \& Schlaghamerský 2013).

The closest comparison, however, is found in the Burgess Shale 'polychaete' Burgessochaeta setigera (Conway Morris $1979 a, b$ ), whose simple strap-shaped chaetae are similarly distinguished by a bifid tip with asymmetric prongs (Fig. 4F; see Eibye-Jacobsen 2004). Even so, the asymmetry of Burgessochaeta chaetae is conspicuously more pronounced than in the File Haidar forms, with the lateral prongs diverging only distally to yield a distinctively splayed ' $\mathrm{Y}$ '-shape tip (the 'lyrate-chaetae' condition; Rouse \& Pleijel 2001); by contrast, the lateral/marginal prongs of the File Haidar specimens are uniformly parallel, leaving space for the expanded brush-like comb (the 'brush-chaetae' condition; Rouse \& Pleijel 2001). Bedding-plane macrofossils do not permit microstructural analysis on a par with SCFs, but if any analogous fine brush is present in Burgessochaeta, it would necessarily be confined to the larger inclined prong as in some modern lyrate-chaetae (Fig. 4F). Nonetheless, the brush-tipped Baltic SCFs are sufficiently distinct to be recognized as a new genus of Burgessochaeta-like annelid, Baltichaeta jormungandr gen. et. sp. nov. (see Systematic Palaeontology below).

Wiwaxiid sclerites. Isolated sclerites of Wiwaxia were recovered from the När Sandstone Member of the Böda Hamn core (Figs 3, 9AC) and from the early-middle Cambrian boundary interval at the base of the Borgholm Formation in the Barstad-2 core (Figs 3, 9Z-AB). The majority of these specimens are asymmetrical, originating from the 'ventrolateral' region of the compound dorsal scleritome. One of the Boda Hamn (File Haidar) specimens (Fig. 9AC) is close to a millimetre long $(0.8 \mathrm{~mm})$, the largest Wiwaxia sclerite yet recovered as an SCF, roughly corresponding to a whole-organism body length of $\sim 3 \mathrm{~cm}$ (see Smith 2014). This same sclerite is further characterized by its blunt termination and associated collar-like thickening, suggesting a biologically mediated loss of the tip.

Most of the recovered Wiwaxia sclerites have prominently developed ribs and in this respect are indistinguishable from the Burgess Shale type species Wiwaxia corrugata. The single specimen with a thickened distal collar appears to be qualitatively different from all other occurrences, but will require a larger sample size to legitimize separate species recognition. Other named species of Wiwaxia have been established on the basis of distinctive rib thickness, sclerite outline, root morphology and/ or surface ornament (Smith et al. 2015a). Given their conspicuously chaeta-like habit and microvillar microstructure, all wiwaxiid sclerites can be confidently placed in total-group Lophotrochozoa, despite on-going debate regarding their phylum-level status (Butterfield 1990b, 2006; Smith 2014; Zhang et al. 2015b; Smith et al. 2015a).

\section{Unresolved metazoans}

Beyond the recognizable ecdysozoan and lophotrochozoan elements, the File Haidar SCF assemblage includes a further range of forms that are clearly bilaterian, but are otherwise lacking taxonomically diagnostic features. The most distinctive of these are sporadically distributed multidenticulate structures represented by series of progressively larger conical-elements, usually connected via a basal membrane (Fig. 10). Such architecture is comparable to the denticulate mouthparts of various bilaterians, including, but not limited to, the jaws of eunicid and phyllodocid polychaete annelids (fossilized as 'scolecodonts'; see Eriksson et al. 2016, fig. 3), molluscan radulae (Butterfield 2008), the feeding apparatus of fossil Wiwaxia/Odontogriphus (Caron et al. 2006) and fossil conodonts. Although some of the File Haidar specimens (e.g. Fig. 10A) are comparable to 'possible wiwaxiid mouthparts' identified in a Cambrian SCF assemblage from Columbia (see Smith et al. 2015a, fig. 3), it is notable that these do not occur in the same samples yielding Wiwaxia sclerites here.

The File Haidar SCF assemblage also includes a range of spines and rods (Figs 3, 9A-T), which in some beds are extremely abundant (e.g. $>200$ in a $50 \mathrm{~g}$ sample). Recurrent morphologies include elongate spinose elements $(20-160 \mu \mathrm{m}$ wide, $150-800 \mu \mathrm{m}$ long), sometimes 


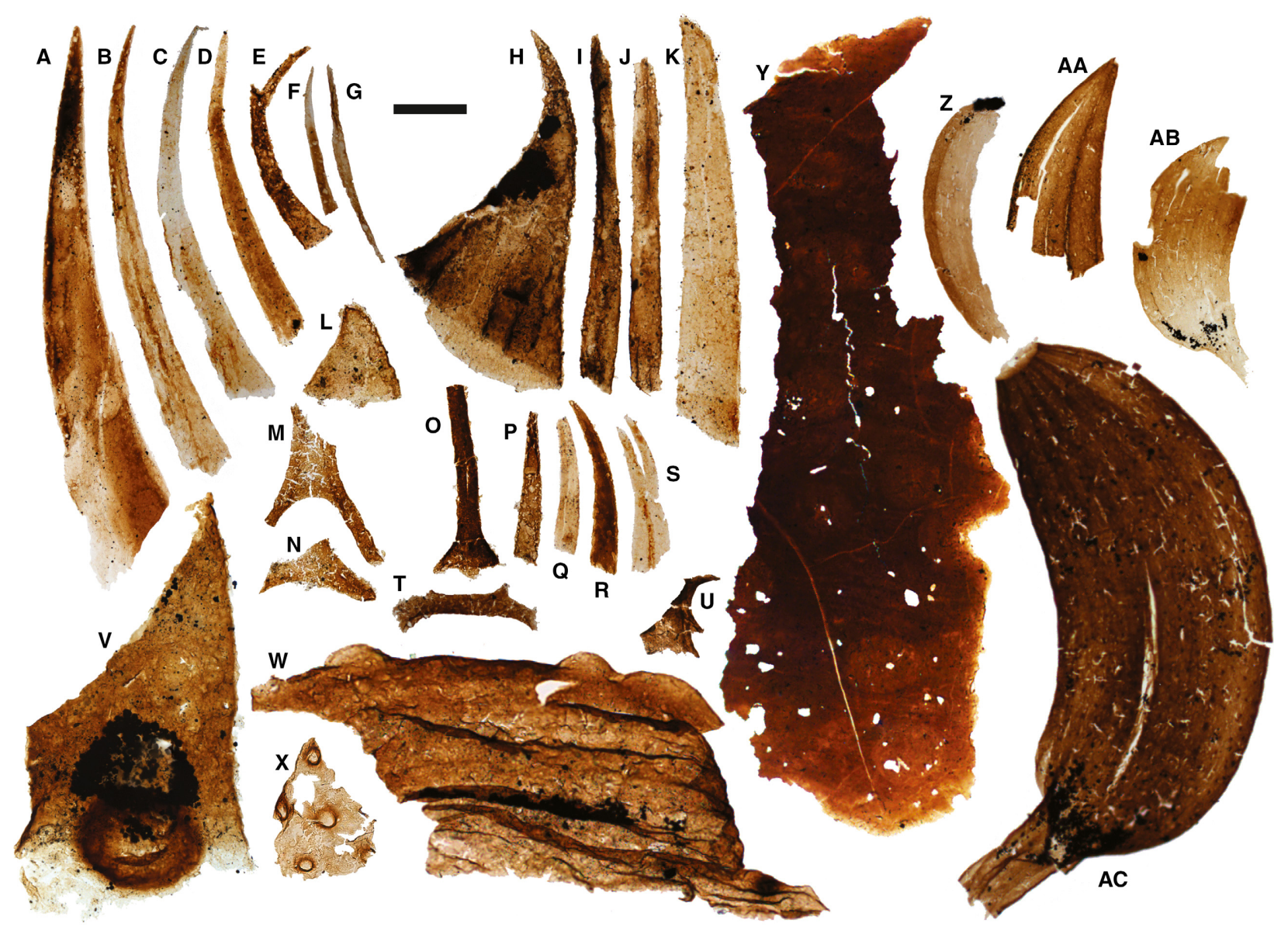

FIG. 9. Wiwaxiid sclerites and taxonomically uncertain metazoan-derived spines and cuticle. A-T, spinose, rod-shaped and unguiliform metazoan elements. $\mathrm{U}$, fragment of unknown metazoan ornament. $\mathrm{V}$, broadly resembles trilobite cuticle, possibly from the anterior part of librigenae (see outline of librigenae in the pouch-brooding trilobite Strenuaeva inflata from the Cambrian Series 2 of Sweden; Cederström et al. 2011, fig. 9). W-Y, fragmentary portions of perforated and 'pock marked' metazoan cuticle, resembles similar cuticular fragments from the early Cambrian Mahto Formation of Alberta, Canada (see Butterfield 2008, fig. 9); thick cuticle Y, possesses broad ( $\sim 70 \mu \mathrm{m}$ diameter) circular to hexagonal indentations. Z-AC, wiwaxiid sclerites. All slide numbers have the prefix NRM PZ X: A-C, F, G, S, T, 6240; D-R, 6239; U, 6166; V, 6226; W, Y, 6252; X, 6253; Z-AB, 6250; AC, 6228. Sample depths from BH-1 core: V, $112.4 \mathrm{~m}$; AC, 118.20 m. Sample depths from Bå-2 core: A-T, 49.98 m; W, Y, 70.90 m; X, 70.25 m; Z, AA, AB, $50.50 \mathrm{~m}$. Sample depths from Gr-1 core: U, $651.07 \mathrm{~m}$. Scale bar represents $100 \mu \mathrm{m}$.

preserved as semi-articulated clusters (Fig. 9B, I-K, S); other associated forms have a stouter construction (Fig. 9H) or exhibit rod-like, unguiliform or 'X-shaped' morphologies (Fig. 9L-O, T). A number of these SCFs are reminiscent of various SSF taxa (cf. Pyle et al. 2006, fig. 6), in particular the clustered spines which resemble demineralized versions of the 'protoconodont' element Protohertzina (Missarzhevsky 1973).

\section{Non-metazoan problematica}

There is nothing specifically metazoan about SCFs of course, the only qualifying criteria being acid resistance and sufficiently large dimensions to be seen and hand- picked $(>40-50 \mu \mathrm{m})$. It is certainly notable that a majority of the File Haidar SCFs are metazoan, but there is a conspicuous subset that are demonstrably not. We include these non-metazoan SCFs here because they represent a further range of forms that have been systematically overlooked/destroyed by conventional techniques, and for what they contribute to the larger scale palaeoenvironmental and taphonomic patterns. Apart from animals, carbonaceous fossils of early Cambrian age might conceivably include fungi, protistan-grade eukaryotes and prokaryotes, though these can often be difficult to distinguish solely on the basis of fossil morphology.

Despite their problematic affinities, some of the nonmetazoan SCFs in the File Haidar assemblage are sufficiently distinctive to be recognized as biologically 
FIG. 10. Multi-denticulate metazoan SCFs. A-D, from File Haidar Formation. E, similar multi-denticulate SCF from the early Cambrian (Stage 3) Lükati Formation, Estonia, for comparison. All slide numbers have the prefix NRM PZ X: A, 6238; B, 6247; C, 6248; D, 6249. Sample depth from FH-1 core: A, $479.00 \mathrm{~m}$. Sample depth from Bå-2 core: B-D, $70.23 \mathrm{~m}$. Scale bar represents $100 \mu \mathrm{m}$.

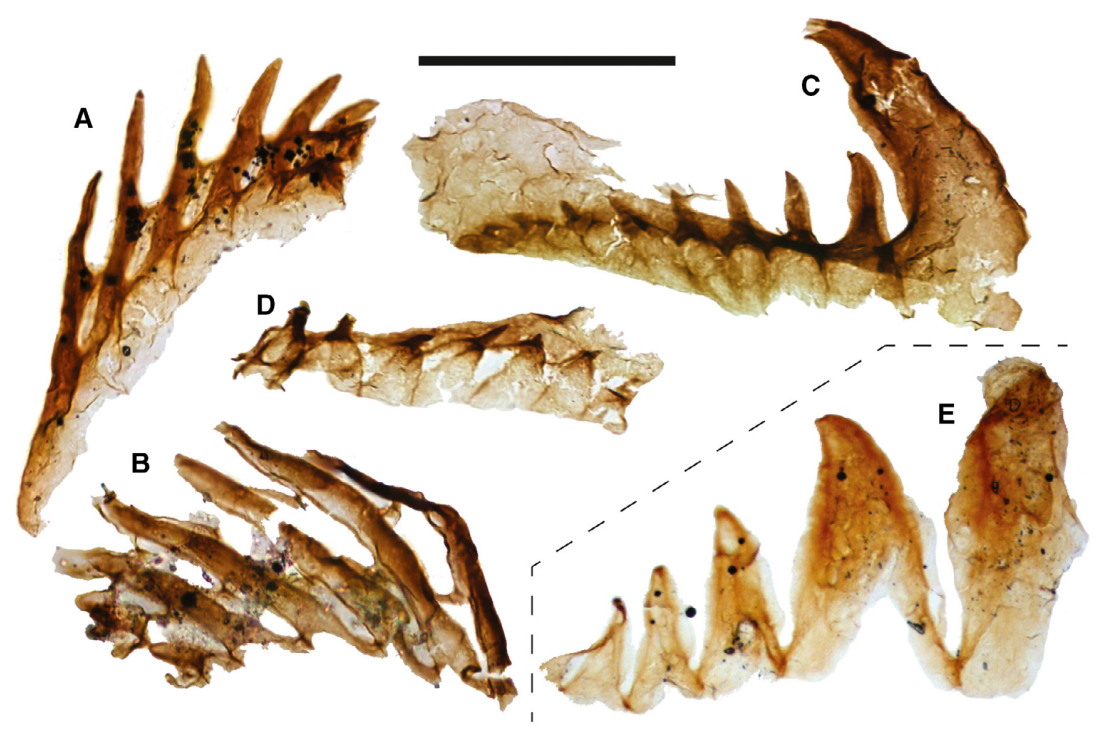

meaningful form-taxa. Among the most common are filamentous fossils recovered from the När Shale and Viklau members (Figs 3, 11A-M). Individual specimens typically comprise a thick $(\sim 70-130 \mu \mathrm{m}$ wide $)$ sinuous main 'filament,' from which a variety of smaller filaments emerge and may themselves branch further (e.g. Fig. 11D). Where preserved, the tips of the main filament and sub-branches taper to a blunt terminus (Fig. 11C). The fossils are further distinguished by the presence of multiple spheroidal to flask-shaped vesicles, anatomically connected to the main filament (Fig. 11E$\mathrm{K}, \mathrm{M}$ ). Carbonaceous fossils of this morphology have not previously been described from the Cambrian, but a loose comparison can be drawn with certain Ediacaranage 'vendotaenids' (Gnilovskaya et al. 1988). We establish a new taxon for these enigmatic organisms: Baltinema rana gen. et. sp. nov. (see Systematic Palaeontology below).

Notably, our processing did not recover any of the spiny/acanthomorphic acritarchs expected in early Cambrian mudstones, and previously reported from the File Haidar Formation (Hagenfeldt 1989, 1994), presumably because they fall below the size range detectable using our hand-picking technique. The only vesicular acritarchs recovered in our samples were clusters of smooth-walled forms (Fig. $11 \mathrm{~N}-\mathrm{S}$ ) which are locally abundant throughout the File Haidar Formation, but become concentrated around horizons yielding metazoan SCFs (Fig. 3). Individual clusters often exceed $100 \mu \mathrm{m}$ (rarely $>500 \mu \mathrm{m})$ in maximum dimension. The absence of consistent cell counts or observable inter-cell connections argues against a green-algal-type coenobial habit (cf. Butterfield 2009) and limits taxonomic resolution; comparable clusters from Proterozoic and Palaeozoic assemblages are usually referred to as Synsphaeridium (e.g. Riedman et al. 2014, fig. 2) but remain of unknown biological affinity.

\section{DISCUSSION}

The array of SCFs described here presents a fundamentally new picture of early Cambrian palaeobiology in the File Haidar Formation and, by extension, Baltica. Although a non-biomineralizing fauna has long been apparent in the File Haidar from its trace fossils (e.g. Jensen 1997), there is a conspicuously limited record of associated body fossils, with the rare though notable records of the arthropod Paleomerus and lobopodian Xenusion (Størmer 1956; Bergström 1971; Krumbiegel et al. 1980; Dzik \& Krumbiegel 1989). Our data provide the first direct record of priapulids, annelids and wiwaxiids in Baltica, along with a range of other metazoans and nonmetazoan forms. At the same time, the broad lithostratigraphic and geographic coverage of our dataset provides a novel view of the local to regional controls on fossil distribution (Figs 1, 3).

\section{Stratigraphical and geographical occurrence}

All stratigraphical members of the File Haidar Formation yielded SCFs, but with significant internal partitioning. Wiwaxiid and protoconodont remains were only found in samples from proximal environments (the Lingulid Sandstone and När Shale of the Bå-2 and BH-1 cores; Fig. 3), while samples bearing annelid and priapulid remains were confined to outboard settings and tended to co-occur with concentrations of Baltinema rana gen. et sp. nov. 

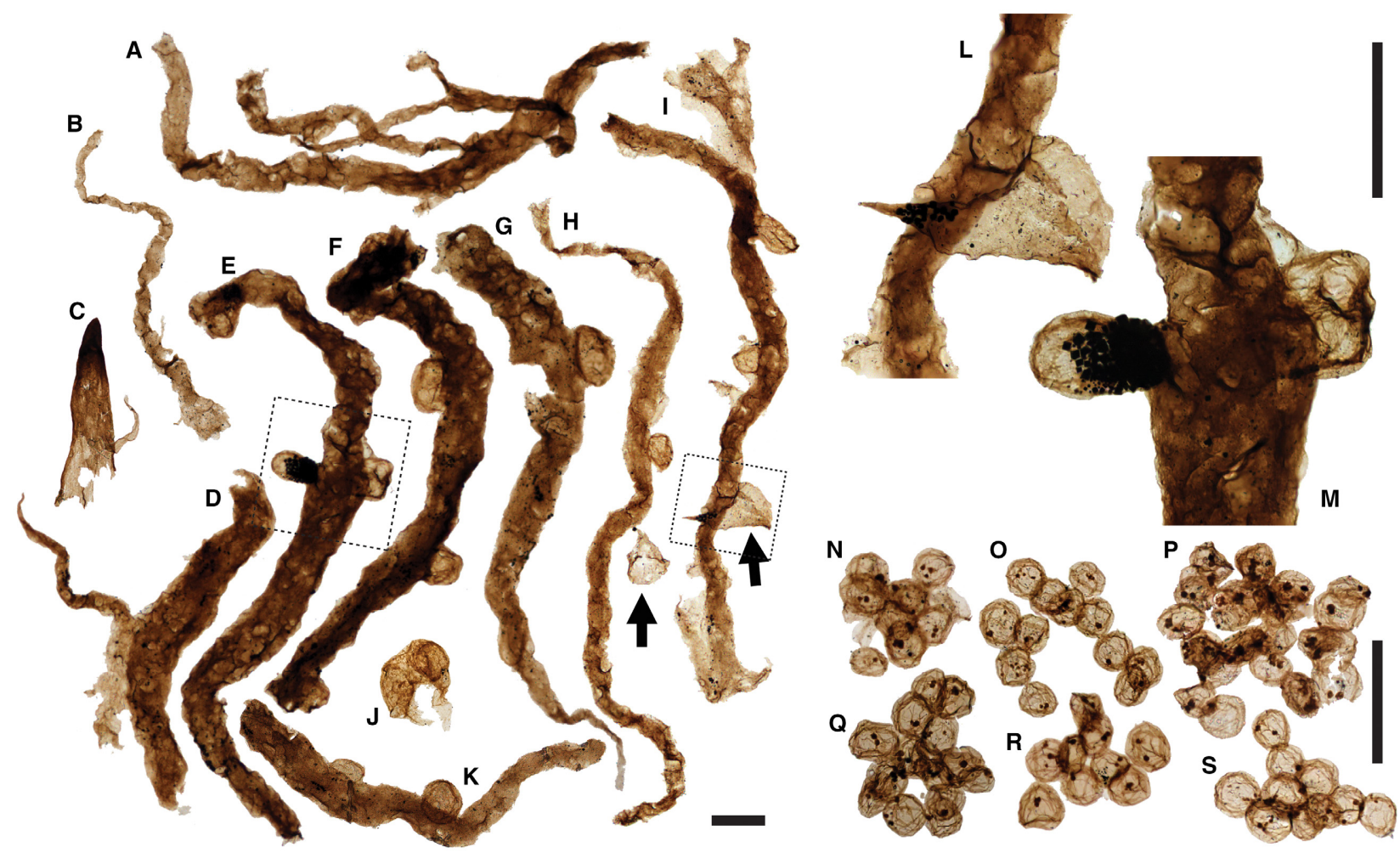

FIG. 11. Problematica. A-M, Baltinema rana gen. et sp. nov; E, holotype specimen (England-finder co-ordinates; H.36-4); arrows indicate 'Ceratophyton'-type scalidophoran spines fortuitously superimposed on filaments; L, close-up of spine from dashed box in specimen I; M, close-up of vesicular outgrowths from dashed box in holotype specimen E. N-S, clusters of smooth-walled vesicular acritarchs. All slide numbers have the prefix NRM PZ X: A-B, D-G, J, M, 6204; C, 6200; H-I, L, P, 6203; K, 6201; N, R, 6194; O, 6193; Q, 6192; S, 6197. Sample depths from Gr-1 core: A-M, P, $653.00 \mathrm{~m}$; N, O, Q, R, S, $651.10 \mathrm{~m}$. All scale bars represent $100 \mu \mathrm{m}$.

and acritarch clusters (the Viklau and När Shale of the FH-1 and Gr-1 cores; Fig. 3). Potentially, these patterns reflect regional palaeobathymetric controls on distribution (see Nielsen \& Schovsbo 2011). No SCFs were recovered from coarser sandstone units, but even within silt- and mud-dominated facies, productive samples were limited to stratigraphically discrete horizons separated by extended intervals noticeably devoid of fossils (Fig. 3). One of the most recurrent features shared by fossil-bearing samples is the localized abundance of cross-cutting and vertical burrows, often accompanied by the presence of sand-sized glauconite (typically in mudstone-hosted lenses), phosphorite clasts, and syneresis or dewatering cracks filled with coarser sand (Figs 3, 12; see Nielsen \& Schovsbo 2011). Termed Kråksten or 'crow-rock' in the regional literature (e.g. Hadding 1924), these conspicuously bioturbated and glauconitic sediments have been interpreted as sub-sequence drowning surfaces (cf. Possamentier \& Allen 1999), where local sediment supply is outstripped by sea level rise (Nielsen \& Schovsbo 2011; Álvaro et al. 2016). Time-averaging during such episodes of sediment-starvation could conceivably account for the increased bioturbation as successive communities of burrowers colonized the same sediment tier (Bromley 1996; McIlroy 2004).

The occurrence of organic-walled fossils in bioturbated sediments is unexpected, particularly in light of the strong negative correlation between Burgess Shale-type preservation and bioturbation (Orr et al. 2003). Recognizable ichnogenera associated with SCF-bearing horizons in the File Haidar Formation cores include Teichichnus, Treptichnus and Gyrolithes. Insofar as at least some treptichnid ichnofossils may be the traces of priapulid-like worms (Orłowski \& Żylińska 1996; Dzik 2005, 2007), and Cambrian priapulids are known to be generalist predators/scavengers (Huang et al. 2004; Vannier 2012), it is notable that all of the priapulid sclerites and annelid chaetae in this study were recovered from burrowed sediments (see Fig. 3). Unlike their macrofossil counterparts, SCFs are relatively immune to physical disturbance, moderate levels of time averaging and even gut-passage (e.g. Vannier 2012). As such, the enhanced 
FIG. 12. Microfacies typical of fossiliferous/SCF-productive horizons. A-C, core material from Gr-1 core: A, 645.65-645.70 m, containing syneresis cracks and Teichichnus burrows; B-C, close-ups of A, showing syneresis cracks in finely laminated mudstone (green-grey) filled with coarser sandstone (pale yellow), these have subsequently been deformed through compaction. D, plan view of bioturbated core from $479.03 \mathrm{~m}$ of the FH-1 core. Scale bars represent: $1 \mathrm{~cm}(\mathrm{~A}, \mathrm{D}) ; 4 \mathrm{~mm}$ (B, C).

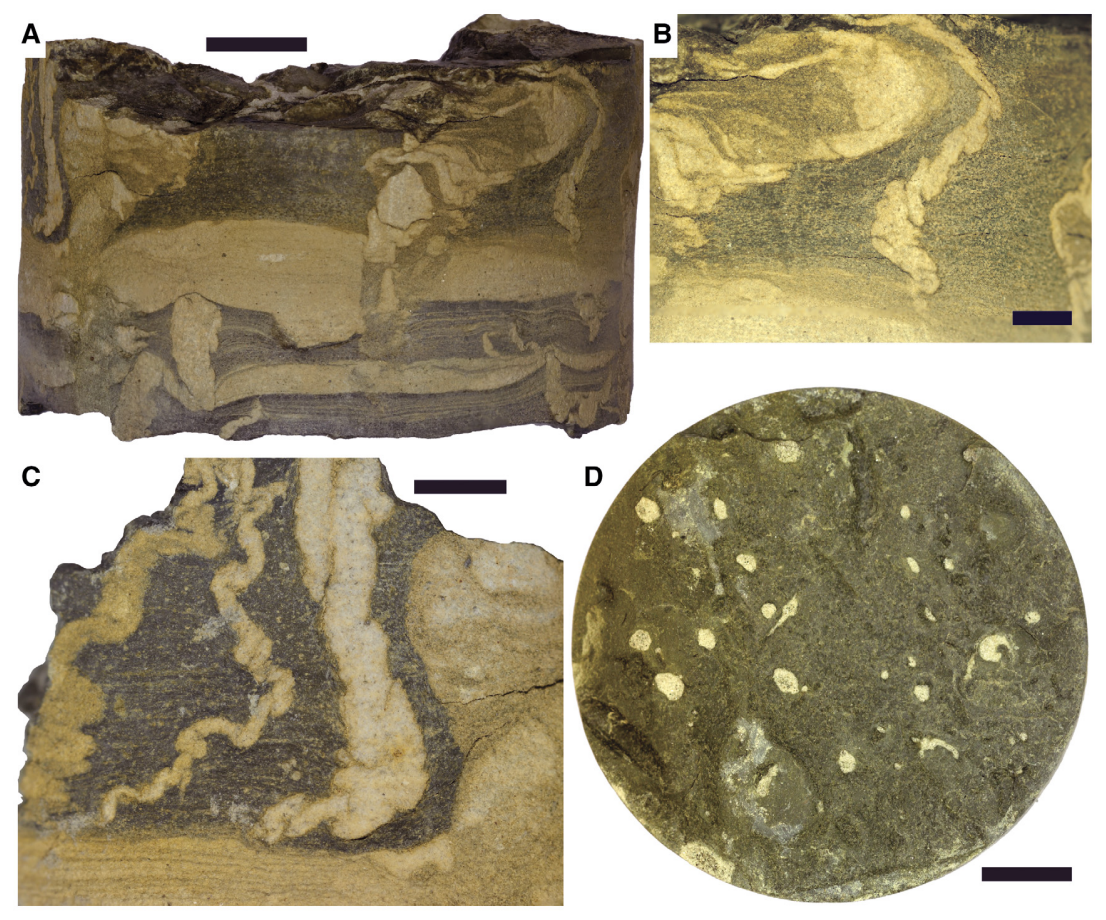

recovery of SCFs in bioturbated horizons may well derive from their localized concentration by scavenging metazoans, with or without the compounding effects of low sediment input and associated time averaging. To this extent, the distribution of SCFs is often more comparable to that of biostratinomically recalcitrant shelly fossils than to delicate articulated carcasses or moults, a factor with important implications for future studies.

\section{Global significance}

With a Cambrian palaeolatitude of $30-60^{\circ}$ and clear separation from any other contemporaneous cratons, Baltica offers an important new view of early palaeobiogeographical partitioning. Our recovery of diverse SCFs from the File Haidar represents the first significant occurrence of non-biomineralizing 'Burgess Shale-type' metazoans from this palaeocontinent. New sclerites from Baltica confirm the presence of Wiwaxia on every major Cambrian craton (Fig. 13). With the addition of Baltiscalida njorda gen. et sp. nov., the record of Cambrian priapulids also acquires a fully global coverage (Fig. 13). In contrast to the cosmopolitan wiwaxiids and priapulids (Figs 13, 14), the chaetae of annelids have not featured in dispersed SCFs assemblages before now, despite their localized extraction from Burgess Shale macrofossils (Butterfield 1990b) and their demonstrable recalcitrance in actualistic taphonomic studies (Briggs \& Kear 1993). Indeed, Baltichaeta jormunganda gen. et sp. nov. represents one of only eight known Cambrian polychaete taxa, and the only one known from beyond palaeotropical, macroscopic BSTLagerstätten (Figs 13, 14).

Surprisingly, the File Haidar assemblage is broadly comparable to lower palaeolatitude BST 'worm'-biotas from Laurentia and South China, which also exhibit a predominance of priapulid, palaeoscolecid, protoconodont, wiwaxiid and polychaete 'worms' (cf. Conway Morris 1989a, b; Han et al. 2008). At least at these coarse taxonomic levels, there appears to be little indication of palaeobiogeographical or palaeolatidudinal partitioning; in marked contrast to the pronounced endemism displayed by many contemporaneous shelly taxa (cf. Samson et al. 1990; Meert \& Lieberman 2008). The File Haidar SCFs do, however, exhibit significant differences at lower taxonomic levels. Although priapulids and polychaetes are present, none of these is directly comparable to previously described species or genera. Both Baltiscalida and Baltichaeta could well be endemic to Baltica and/or high palaeolatidudes (cf. Smith et al. 2015b), though limited sampling leaves this open to further validation. Certainly the macrofossil record of polychaetous annelids in the Cambrian, currently known from just four biotas worldwide, is too sparse to derive a reliable biogeographic signal (Figs 13, 14). Even so, there are strong grounds for expecting inter-regional distinctions in species distributions (Meert \& Lieberman 2008; Alroy 2010), and the fine level of detail provided by SCFs has the potential to illuminate such patterns (cf. Smith et al. 2015b). 


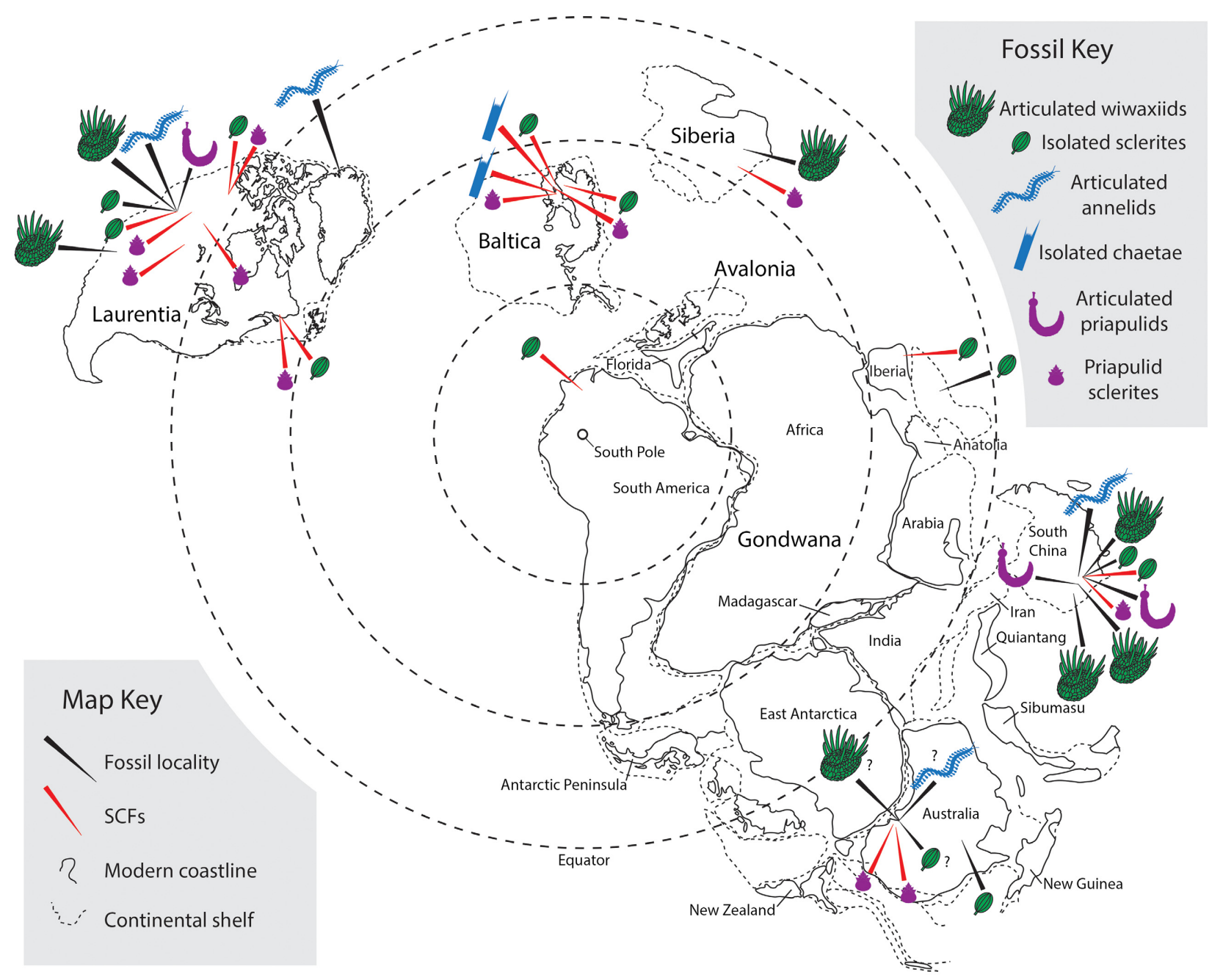

FIG. 13. Global distribution of palaeocontinents in the early Cambrian showing reported occurrences of Wiwaxia macrofossils and disarticulated sclerites, priapulid macrofossils and SCFs, and 'polychaete' annelid macrofossils and isolated chaetae. Palaeogeographic reconstruction after McKerrow et al. (1992), Kirschvink et al. (1997) and Torsvik \& Cocks (2013). See Fig. 14 for details of occurrence data.

Despite the predominance of priapulids (including palaeoscolecids) in almost all Burgess Shale-type 'worm' biotas (Conway Morris 1979a, b; Zhang et al. 2006; Harvey et al. 2012a; Smith et al. 2015b) it is notable that both priapulids and polychaete annelids have been recovered together from the File Haidar sediments; indeed, B. jormunganda gen. et sp. nov. chaetae are locally far more abundant, and often better preserved, than the associated priapulid and wiwaxiid sclerites. Such expression rules out differential histology as a significant factor in the global expression of Cambrian polychaetes, pointing instead to their general marginalization in priapulid-dominated Cambrian oceans (Conway Morris 1979a, 1989b). At another level, however, it is clear there are fundamental differences between the 'typical' Burgess Shale-type biotas found in deeper water, low-oxygen (dysaerobic) environments, and those from shallower more fully oxygenated facies (Butterfield \& Harvey 2012). The epicratonic Mount Cap and Deadwood biotas of western Canada, for example, include a surprisingly modern diversity of crustacean and molluscan SCFs, none of which appear in contemporaneous deeper water biotas (Harvey \& Butterfield 2008; Harvey et al. 2012b). Intriguingly, both the Mount Cap and Deadwood successions contain bioturbated and syneresis-cracked glauconitic sandstone horizons, directly comparable to the fossiliferous 'Kråksten' facies in the Baltic Basin. Once again, it is too soon to draw broad conclusions, but the discovery of a new polychaete taxon in well oxygenated/bioturbated horizons of the File Haidar Formation suggests that the current record is steeply biased in favour of dysaerobic, priapulid-dominated environments conducive to the preservation of Burgess Shale-type macrofossils. 


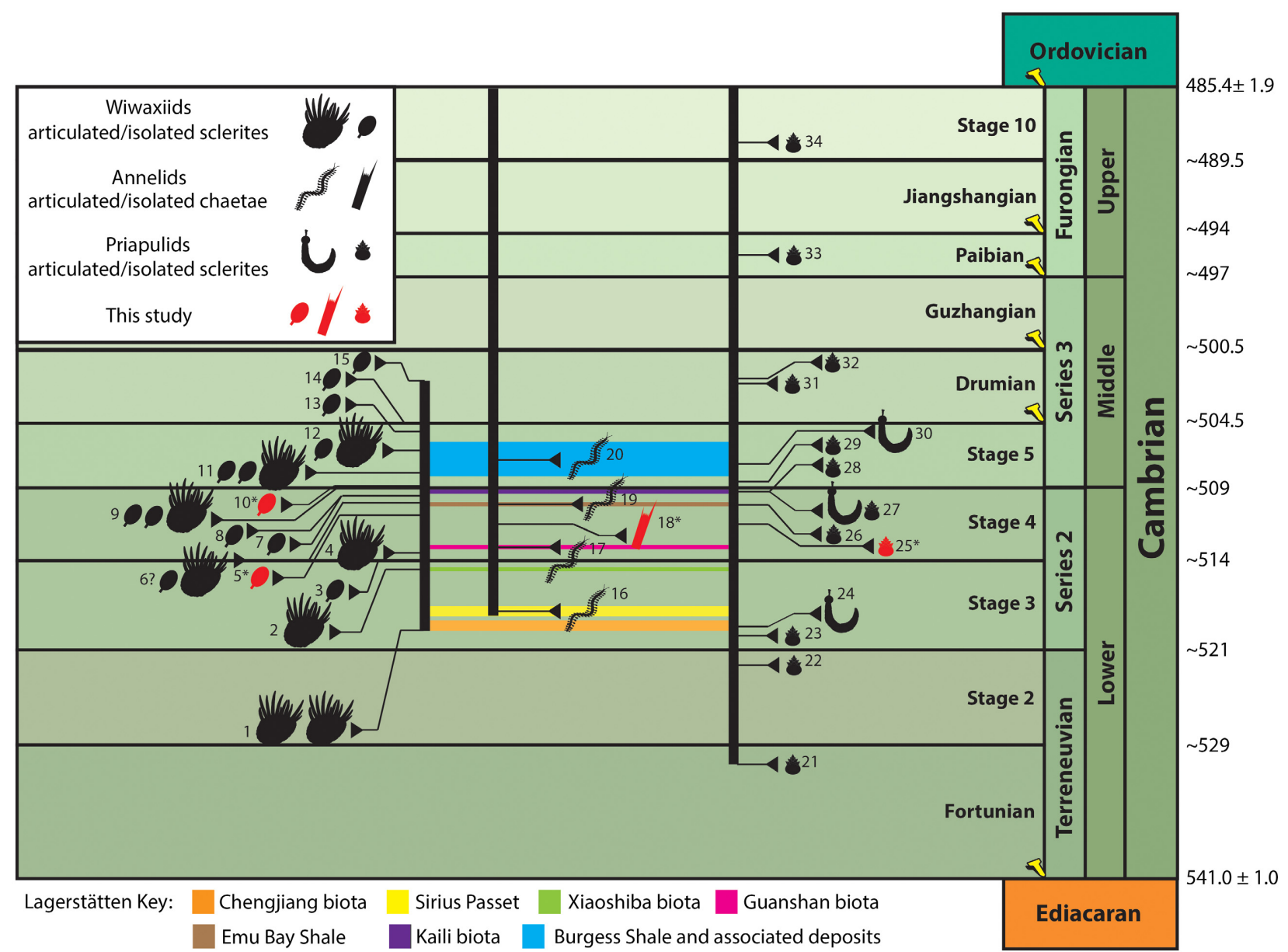

FIG. 14. Stratigraphical occurrence of wiwaxiids, 'polychaete' annelids and priapulids in the Cambrian, showing temporal distribution of those identified from the File Haidar Formation in relation to other known SCFs and bedding-plane macrofossils. Occurrence key: 1, Wiwaxia papilio and Wiwaxia sp., Chengjiang, Kunming, China (Zhao et al. 2015; Zhang et al. 2015a, b); 2, Wiwaxia foliosa, Xiaoshiba, Kunming, China (Yang et al. 2014); 3, Lancara Formation, northern Spain (Palacios et al. 2014); 4, Sinsk Shale, Siberia, Russia (Ivantsov et al. 2005a, b); 5*, File Haidar Formation, Öland, Sweden (this study); 6?, Emu Bay Shale, South Australia (C. Nedin pers. comm. in Porter 2004); 7, Mount Cap Formation, NWT, Canada (Harvey \& Butterfield 2011); 8, Forteau Formation, Newfoundland, Canada (Butterfield \& Harvey 2012); 9, Wiwaxia taijiangensis, Kaili, Guizhou, China (Zhao et al. 1994); 10*, File Haidar - Borgholm Formation boundary, Östergotland, Sweden (this study); 11, Wiwaxia corrugata, Burgess Shale, British Columbia, Canada (Walcott 1911); 12, Wiwaxia herka, Utah, USA (Conway Morris et al. 2015); 13, Buchava Formation, Czech Republic (Fatka et al. 2011); 14, Georgina Basin, Australia (Southgate \& Shergold 1991; Porter 2004); 15, Llanos Basin, Colombia (Smith et al. 2015a); 16, Sirius Passet, Greenland, two species (Parry et al. 2015); 17, Guanshanchaeta felicia, Guanshan biota, China (Liu et al. 2015); 18*, Baltichaeta jormunganda, File Haidar Formation, Sweden (this study); 19, Emu Bay Shale, South Australia (Greg Edgecombe, pers. comm. 2013 in Parry et al. 2014; figured but undescribed by Paterson et al. 2016); 20, Burgess Shale and associated units, British Columbia, Canada, five species plus an additional undescribed form from Marble Canyon (see Parry et al. 2015); 21, Kessyusa Formation, Siberia, Russia, priapulid teeth SCFs (Nagovitsin 2011); 22-24, 26-34, see Smith et al. 2015b; 25, Baltiscalida njorda, File Haidar Formation, Sweden (this study). Golden spike symbols indicate formally defined stage boundaries.

\section{SYSTEMATIC PALAEONTOLOGY}

We establish three new monospecific genera based on SCF material recovered from the File Haidar Formation. All specimens are permanently mounted on glass slides and are housed in the Swedish Museum of Natural History, Stockholm (NRM). Although these taxa are established on the basis of disarticulated elements, they are sufficiently distinctive to be used, in practice, as natural biological taxa. Like Halkieria (Conway Morris \& Peel 1990) and the conodont animal (Briggs et al. 1983), we expect the whole-organism morphology associated with these SCFs to be discovered in due course. Our approach reflects prevailing practices in the taxonomy of SSFs 
derived from multi-element scleritomes (e.g. Skovsted \& Peel 2007; Topper et al. 2009).

Superphylum ECDYSOZOA Aguinaldo et al., 1997 CYCLONEURALIA

SCALIDOPHORA

Total group of Phylum PRIAPULIDA Delage \& Hérouard, 1897

Incertae familiae

\section{Genus BALTISCALIDA nov.}

LSID. urn:lsid:zoobank.org:act:DE398F3F-38A7-4D54-B7AA70666CDB590E

Derivation of name. With reference to the Baltic Basin.

Type species. Baltiscalida njorda sp. nov. by monotypy.

Diagnosis. As for type species.

Baltiscalida njorda sp. nov. Figure $5 B-E$, $G$

LSID. urn:lsid:zoobank.org:act:D586CA6B-DD5A-413F-8D33E9B8157EB280

Derivation of name. After the sea deity, Njord, in Norse mythology.

Holotype. NRM PZ X 6152, Fig. 5B; slide 6152, England-finder coordinates N.50-3. 4 designated paratypes: Fig. 5C-E, G (NRM PZ X 6150, 6156, 6176, 6184).

Diagnosis. A priapulid or priapulid-like scalidophoran with pharyngeal teeth that have an acute arch tapering to a central prong which is aligned with the angle of the arch; at least three tooth morphotypes present. In all teeth the arch is denticulate, with hollow distally-projecting stout marginal denticles which taper to a point and occasionally branch. Type 1 teeth with a narrow elongate outline and numerous short, closely-spaced denticles extending almost to the tip. Type 2 teeth with an equant outline and medium to long denticles arranged along a size gradient with the longest denticles nearest the prong. Type 3 teeth with an elongate outline and sparse denticles of moderate length with no size gradient in their distribution, and typically asymmetrically arranged with a gap between the distalmost denticles and the arch apex/prong.

Distribution. Viklau and När Shale Members of the early Cambrian (Stage 4) File Haidar Formation, Gotland, Sweden (known from Grötlingbo-1 and File Haidar-1 cores).
Remarks. The three morphotypes of isolated pharyngeal teeth of B. njorda gen. et sp. nov. commonly co-occur in samples and occupy a range of morphologies that is typically observed within a single species of priapulid. In addition, the three principle tooth morphotypes commonly co-occur with other tooth- and scalid-like morphologies (Figs 6,7 ) which potentially belong to the same species; these other sclerites, however, lack distinctive features and are not formally included in the description. Occasionally smaller sclerites (e.g. Fig. 5M) display an intermediate morphology between types 2 and 3 teeth, probably reflecting ontogeny or variation along the introvert. The basal pad in B. njorda teeth is usually poorly preserved, suggesting it was comparatively labile in contrast to the heavily sclerotized spinose portions. A possible 'spur' may be developed in some specimens and is usually visible in co-occurring scalids; this is commonly adpressed to the remainder of the sclerite, however, obscuring its original morphology and orientation.

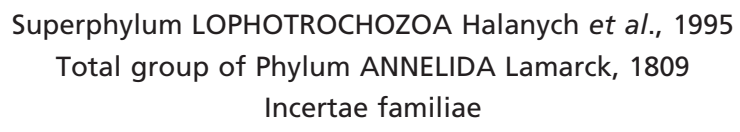

Genus BALTICHAETA nov.

LSID. urn:lsid:zoobank.org:act:C082DEC4-7DAB-4C75-864923FEE6E1135B

Derivation of name. With reference to the Baltic Basin.

Type species. Baltichaeta jormunganda sp. nov. by monotypy.

Diagnosis. As for type species.

\section{Baltichaeta jormunganda sp. nov. Figures $8 \mathrm{~A}-\mathrm{V}$}

LSID. urn:lsid:zoobank.org:act:5B489254-058E-47EE-9B4A79987E7D7596

Derivation of name. After Jormungandr, a sea serpent in Norse mythology.

Holotype. NRM PZ X 6154, Fig. 8A; slide 6154, England-finder coordinates L.49-4. 21 designated paratypes: Fig. 8B-V (see caption for slide numbers).

Diagnosis. An annelid with simple comb chaetae. Bladelike shafts terminate distally in extended lateral prongs, separated by an interval of fine serrations. Prongs always project beyond the brush tip and may be either symmetrically or asymmetrically developed to different degrees. 
Serrations of the comb have acute tips in larger specimens or sub-rounded tips in smaller forms. Comb may be laterally divided into thirds by two prominent serrations approximately twice the size of the average for the comb. Densely-packed linear striations run the internal length of the chaetae, perpendicular to this is a series of equally spaced horizontal ridges, spaces between ridges increasing with respect to the size of the chaetae.

Distribution. Viklau and När Shale Members of the early Cambrian (Stage 4) File Haidar Formation, Gotland, Sweden (known from Grötlingbo-1 and File Haidar-1 cores).

\section{Incertae sedis}

\section{Genus BALTINEMA nov.}

LSID. urn:lsid:zoobank.org:act:B253AEE3-AD94-4B51-8C7534E53FF543C1

Derivation of name. With reference to the Baltic Basin.

Type species. Baltinema rana sp. nov. by monotypy.

Diagnosis. As for type species.

\section{Baltinema rana sp. nov. Figure $11 \mathrm{~A}-\mathrm{M}$}

LSID. urn:lsid:zoobank.org:act:7B79C52A-EDAF-40EC-A3C7CC6B03F86409

Derivation of name. After the sea deity, Ràn, in Norse mythology.

Holotype. NRM PZ X 6204, Fig. 11E; slide 6204, England-finder coordinates H.36-4. 8 designated paratypes: Fig. 11A-D, F-K (see caption for slide numbers).

Diagnosis. Filamentous organisms consisting of a sinuous primary axis bearing medially distributed secondary sinuous branches and globose lateral outgrowths. Length highly variable but always considerably exceeds the width. Main axis has an irregular 'pock-marked' appearance and is typically darker than the secondary structures. Apical terminations of primary axis taper to a rounded tip. Globose outgrowths roughly the width of the parent axis occur either in isolation or in pairs on opposing sides of the main axis. Branches resemble smaller versions of the primary axis and occasionally sub-branch but do not bear globose extensions.

Distribution. Viklau and När Shale Members of the early Cambrian (Stage 4) File Haidar Formation, Gotland and Öland, Sweden (known from Grötlingbo-1, File Haidar-1 and Böda Hamn1 cores).
Remarks. The biological affinity of these forms is unresolved. The thick, wrinkled, central axis of B. rana does not appear to be composed of a compound cluster of filaments, but instead has conspicuous surficial and internal pock-marked cavities throughout. In overall architecture B. rana bears similarities to certain Ediacaran 'vendotaenids' such as Eoholynia (see Urbanek \& Rozanov 1983, fig. XLV-1; Gnilovskaya et al. 1988) and other Neoproterozoic microfossils such as Pseudodendron (see Butterfield et al. 1994, fig. 28); however, it is significantly smaller than the dichotomously branching Eoholynia, and Pseudodendron lacks globose outgrowths.

Acknowledgements. We thank Linda Wickström (Geological Survey of Sweden) for her help in sample collection and logistical work at the Swedish drillcore repository, Eggebyholm, and Heikke Bauert and Ursula Toom (Tallinn University of Technology) for help in drillcore sampling in Estonia. We also thank Sören Jensen and an anonymous reviewer for detailed comments on the manuscript. We acknowledge the support of Churchill College, Cambridge (BJS) and Clare Hall College, Cambridge (RG). This research was funded by the Natural Environmental Research Council, UK, grant NE/K005251/1 (BJS, THPH, RG, NJB).

\section{DATA ARCHIVING STATEMENT}

This published work and the nomenclatural acts it contains, have been registered in ZooBank: http://zoobank.org/References/ AB48F49C-9D32-44C4-BDE8-349794BBE51A

Editor. Imran Rahman

\section{REFERENCES}

ADRAIN, J. M., CHATTERTON, B. D. E. and COCKS, L. R. M. 1991. A new species of machaeridian from the Silurian of Podolia, USSR, with a review of the Turrilepadidae. Palaeontology, 34, 637-651.

AGIĆ, H., MOCZYDŁ OWSKA, M. and CANFIELD, D. E. 2016. Reproductive cyst and operculum formation in the Cambrian-Ordovician galeate-plexus microfossils. GFF, 138, 1-17.

AGUinAldo, A. M. A., TURBEVIlle, J. M., LINFORD, L. S., RIVERA, M. C., GAREY, J. R., RAFF, R. A. and LAKE, J. A. 1997. Evidence for a clade of nematodes, arthropods and other moulting animals. Nature, 387, 489-493.

AHLBERG, P. 1984. The Lower Cambrian sequence in Skåne, Sweden. Geologiska Föreningen i Stockholm Förhandlingar, 106, 380-381.

— and BERGSTRÖM, J. 1993. The trilobite Calodiscus lobatus from the Lower Cambrian of Scania, Sweden. Geologiska Föreningen i Stockholm Förhandlingar, 115, 331-334.

- a $\_$and JOHANSSON J. 1986. Lower Cambrian olenellid trilobites from the Baltic Faunal Province. Geologiska Föreningen i Stockholm Förhandlingar, 108, 39-56. 
ÅHMAN, E. and MARTINSSON, A. 1965. Fossiliferous Lower Cambrian at Äspelund on the Skäggenäs Peninsula. Geologiska Föreningen i Stockholm Förhandlingar, 87, 139151.

ALROY, J. 2010. Geographical, environmental and intrinsic biotic controls on Phanerozoic marine diversification. Palaeontology, 53, 1211-1235.

Álvaro, J. J., SHiEldS-ZhoU, G. A., AHLBERG, P., JENSEN, S. and PALACIOS, T. 2016. Ediacaran-Cambrian phosphorites from the western margins of Gondwana and Baltica. Sedimentology, 63, 350-377.

BENGTSON, S. 1968. The problematic genus Mobergella from the Lower Cambrian of the Baltic area. Lethaia, 1, 325-351.

BERGSTRÖM, D. J. 1968. Eolimulus, a Lower Cambrian Xiphosurid from Sweden. Geologiska Föreningen i Stockholm Förhandlingar, 90, 489-503.

— 1971. Paleomerus - merostome or merostomoid. Lethaia, 4, 393-401.

_ 1973. Organization, life, and systematics of trilobites. Fossils \& Strata, 2, $69 \mathrm{pp}$.

— and AHLBERG, P. 1981. Uppermost Lower Cambrian biostratigraphy in Scania, Sweden. Geologiska Föreningen $i$ Stockholm Förhandlingar, 103, 193-214.

BRIGGS, D. E. G. and KEAR, A. J. 1993. Decay and preservation of polychaetes: taphonomic thresholds in soft-bodied organisms. Paleobiology, 19, 107-135.

— CLARKSON, E. N. K. and ALDRIDGE, R. J. 1983. The conodont animal. Lethaia, 16, 1-14.

BROMLEY, R. G. 1996. Trace fossil assemblages, diversity and facies. 208-253. In BROMLEY, R. G. Trace fossils: biology, taphonomy and applications. $2^{\text {nd }}$ edn. Taylor \& Francis.

BUTTERFIELD, N. J. 1990a. Organic preservation of nonmineralizing organisms and the taphonomy of the Burgess Shale. Paleobiology, 16, 272-286.

- 1990b. A reassessment of the enigmatic Burgess Shale fossil Wiwaxia corrugata (Matthew) and its relationship to the polychaete Canadia spinosa Walcott. Paleobiology, 16, 287-303.

— 1994. Burgess Shale-type fossils from a Lower Cambrian shallow-shelf sequence in northwestern Canada. Nature, 369, 477-479.

— 2003. Exceptional fossil preservation and the Cambrian Explosion. Integrative \& Comparative Biology, 43, 166-177.

_ 2006. Hooking some stem-group 'worms': fossil lophotrochozoans in the Burgess Shale. BioEssays, 28, 1161-1166.

— 2008. An Early Cambrian radula. Journal of Paleontology, 82, 543-554.

2009. Modes of pre-Ediacaran multicellularity. Precambrian Research, 173, 201-211.

— and HARVEY, T. H. P. 2012. Small carbonaceous fossils (SCFs): a new measure of early Paleozoic paleobiology. Geology, 40, 71-74.

— and NICHOLAS, C. J. 1996. Burgess Shale-type preservation of both non-mineralizing and 'shelly' Cambrian organisms from the Mackenzie Mountains, northwestern Canada. Journal of Paleontology, 70, 893-899.

— KNOLL, A. H. and SWETT, K. 1994. Paleobiology of the Neoproterozoic Svanbergfjellet Formation, Spitsbergen. Lethaia, 27, 76.
CARON, J.-B., SCHELTEMA, A., SCHANDER, C. and RUDKIN, D. 2006. A soft-bodied mollusc with radula from the Middle Cambrian Burgess Shale. Nature, 442, 159-163.

CAWOOD, P. A. and PISAREVSKY, S. A. 2006. Was Baltica right-way-up or upside-down in the Neoproterozoic? Journal of the Geological Society, 163, 753-759.

CederströM, P., AHlberG, P., Nilsson, C. H., AHLGREN, J. and ERIKSSON, M. E. 2011. Moulting, ontogeny and sexual dimorphism in the Cambrian ptychopariid trilobite Strenuaeva inflata from the northern Swedish Caledonides. Palaeontology, 54, 685-703.

COCKS, L. R. M. and TORSVIK, T. H. 2005. Baltica from the late Precambrian to mid-Palaeozoic times: the gain and loss of a terrane's identity. Earth-Science Reviews, 72, 39-66.

CONWAY MORRIS, S. 1979a. Middle Cambrian polychaetes from the Burgess shale of British Columbia. Philosophical Transactions of the Royal Society of London B, 285, 227-274.

— 1979b. The Burgess Shale (Middle Cambrian) fauna. Annual Review of Ecology \& Systematics, 10, 327-349.

1989a. Burgess Shale faunas and the Cambrian explosion. Science, 246, 339-346.

1989b. The persistence of Burgess Shale-type faunas: implications for the evolution of deeper-water faunas. Transactions of the Royal Society of Edinburgh: Earth Sciences, 80, 271-283.

- and PEEL, J. S. 1990. Articulated halkieriids from the Lower Cambrian of north Greenland. Nature, 345, 802-805. - SElden, P. A., GUNTher, G., JAMison, P. G. and ROBISON, R. A., 2015. New records of Burgess Shaletype taxa from the middle Cambrian of Utah. Journal of Paleontology, 89, 411-423.

DALEY, A. C. and LEGG, D. A. 2015. A morphological and taxonomic appraisal of the oldest anomalocaridid from the Lower Cambrian of Poland. Geological Magazine, 152, 949955.

DELAGE, Y. and HÉROUARD, E. 1897. Traité de Zoologie concrète. 5. Les vermidiens. Schleicher Frères, Paris.

DONG, X., DONOGHUE, P. C. J., CUNNINGHAM, J. A., LIU, J. and CHENG, H. 2005. The anatomy, affinity, and phylogenetic significance of Markuelia. Evolution \& Development, 7, 468-482.

DÓZSA-FARKAS, K. and SCHLAGHAMERSKÝ, J. 2013. Hrabeiella periglandulata (Annelida: 'Polychaeta') - do apparent differences in chaetal ultrastructure indicate the existence of several species in Europe. Acta Zoologica Academiae Scientiarum Hungaricae, 59, 143-156.

DUNN, C. W., HEJNOL, A., MATUS, D. Q., PANG, K., BROWNE, W. E., SMITH, S. A., SEAVER, E., ROUSE, G. W., OBST, M., EDGECOMBE, G. D., SØRENSEN, M. V., HADDOCK, S. H. D., SCHMIDT-RHAESA, A., OKUSU, A., KRISTENSEN, R. M., WHEELER, W. C., MARTINDALE, M. Q. and GIRIBET, G. 2008. Broad phylogenomic sampling improves resolution of the animal tree of life. Nature, 452, 745-749.

DZIK, J. 2005. Behavioral and anatomical unity of the earliest burrowing animals and the cause of the 'Cambrian explosion'. Paleobiology, 31, 503-521.

— 2007. The Verdun Syndrome: simultaneous origin of protective armour and infaunal shelters at the Precambrian- 
Cambrian transition. Geological Society, London, Special Publications, 286, 405-414.

— and KRUMBIEGEL, G. 1989. The oldest 'onychophoran' Xenusion: a link connecting phyla? Lethaia, 22, 169-181.

— and LENDZION, K. 1988. The oldest arthropods of the East European Platform. Lethaia, 21, 29-38.

EIBYE-JACOBSEN, D. 2004. A reevaluation of Wiwaxia and the polychaetes of the Burgess Shale. Lethaia, 37, 317335.

EKLUND, C. 1990. Lower Cambrian acritarch stratigraphy of the Bårstad 2 core, Östergötland, Sweden. Geologiska Föreningen i Stockholm Förhandlingar, 112, 19-44.

ERIKSSON, M. E., LINDSKOG, A., SERVAIS, T., HINTS, O. and TONAROVÁ, P. 2016. Darriwilian (Middle Ordovician) worms of southern Sweden. GFF, 138, 502509.

FATKA, O., KRAFT, P. and SZABAD, M. 2011. Shallowwater occurrence of Wiwaxia in the middle Cambrian of the Barrandian area, Czech Republic. Acta Palaeontologica Polonica, 56, 871-875.

FLODÉN, T. 1980. Seismic stratigraphy and bedrock geology of the central Baltic. Stockholm Contributions in Geology, 35, 240 pp.

GARCÍA-BELLIDO, D. C., PATERSON， J. R. and EDGECOMBE, G. D. 2013. Cambrian palaeoscolecids (Cycloneuralia) from Gondwana and reappraisal of species assigned to Palaeoscolex. Gondwana Research, 24, 780-795.

GIRIBET, G., DUNN, C. W., EDGECOMBE, G. D., HEJNOL, A., MARTINDALE, M. Q. and ROUSE, G. W. 2009. Assembling the spiralian tree of life. 52-64. In TELFORD, M. J. AND LITTLEWOOD, D. T. J. (eds). Animal evolution: genes, genomes, fossils, and trees. Oxford University Press.

GNILOVSKAYA, M. B., ISTCHENKO, A. A., KOLESNIKO, C. M., KORENCHUK, L. V. and UDALSTOV, A. P., 1988. Vendotaenids of the East European Platform. Nauka. 140 pp. [in Russian]

GORDON, D. P. 1975. The resemblance of bryozoan gizzard teeth to 'annelid-like' setae. Acta Zoologica, 56, 283-289.

HADDING, A. 1924. X-ray investigations of clays and some other ceramic substances. Transactions of the Ceramic Society, 24 , p. 27.

HAGENFELDT, S. E. 1989. Low and middle Cambrian acritarchs from Baltic depression and south-central Sweden, taxonomy, stratigraphy and palaeographic reconstruction. PhD Thesis, University of Stockholm, $32 \mathrm{pp}$.

— 1994. The Cambrian File Haidar and Borgholm formations in the Central Baltic and south central Sweden. Stockholm Contributions in Geology, 43, 69-110.

_ and BJERKÉUS, M. 1991. Cambrian acritarch stratigraphy in the central Baltic Sea, Sweden. Geologiska Föreningen i Stockholm Förhandlingar, 113, 83-84.

HALANYCH, K. M., BACHELLER, J. D., AGUINALDO, A. M. A. and LIVA, S. M. 1995. Evidence from 18S ribosomal DNA that the lophophorates are protostome animals. Science, 267, 1641-1643.

HAN, J., ZHANG, Z.-F. and LIU, J.-N. 2008. A preliminary note on the dispersal of the Cambrian Burgess Shale-type faunas. Gondwana Research, 14, 269-276.
HARTZ, E. H. and TORSVIK, T. H. 2002. Baltica upside down: a new plate tectonic model for Rodinia and the Iapetus Ocean. Geology, 30, 255-258.

HARVEY, T. H. P. 2010. Carbonaceous preservation of Cambrian hexactinellid sponge spicules. Biology Letters, 6, 834-837.

— and BUTTERFIELD, N. J. 2008. Sophisticated particlefeeding in a large Early Cambrian crustacean. Nature, 452, 868-871.

_ 2011. Great Canadian Lagerstätten 2. Macro and microfossils of the Mount Cap Formation (Early and Middle Cambrian, Northwest Territories). Geoscience Canada, 38, 165-173.

— DONG, X. and DOnOGHUE, P. C. J. 2010. Are palaeoscolecids ancestral ecdysozoans? Evolution \& Development, 12, 177-200.

— ORTEGA-HERNÁNDEZ, J., LIN, J.-P., YUANLONG, Z. and BUTTERFIELD, N. J. 2012a. Burgess Shale-type microfossils from the Middle Cambrian Kaili Formation, Guizhou Province, China. Acta Palaeontologica Polonica, 57, 423-436.

— VÉLEZ, M. I. and BUTTERFIELD, N. J. 2012b. Exceptionally preserved crustaceans from western Canada reveal a cryptic Cambrian radiation. Proceedings of the National Academy of Sciences, 109, 1589-1594.

HAUSEN, H. 2005. Chaetae and chaetogenesis in polychaetes (Annelida). Hydrobiologia, 535-536, 37-52.

HESSLAND, I. R. 1955. Boring through the Cambrian and Ordovician strata at Böda Hamn, Öland; II, Studies in the lithogenesis of the Cambrian and basal Ordovician of the Böda Hamn sequence of strata. Bulletin of the Geological Institutions of the University of Uppsala, New Series, 35, 35108.

HINZ, I., KRAFT, P., MERGL, M. and MÜLLER, K. J. 1990. The problematic Hadimopanella, Kaimenella, Milaculum and Utahphospha identified as sclerites of Palaeoscolecida. Lethaia, 23, 217-221.

HOLM, G., 1901. Kinnekulles berggrund. Sveriges Geologiska Undersökning Serie C 172, 1-70

HUANG, D.-Y., VANNIER, J. and CHEN, J.-Y. 2004. Anatomy and lifestyles of Early Cambrian priapulid worms exemplified by Corynetis and Anningvermis from the Maotianshan Shale (SW China). Lethaia, 37, 21-33.

IVANTSOV, A. Y. and WRONA, R. 2004. Articulated palaeoscolecid sclerite arrays from the Lower Cambrian of eastern Siberia. Acta Geologica Polonica, 54, 1-22.

— ZHURAVLEV, A. Y., LEGUTA, A. V., KRASSILOV, V. A., MELNIKOVA, L. M. and USHATINSKAYA, G. T. 2005a. Palaeoecology of the Early Cambrian Sinsk biota from the Siberian Platform. Palaeogeography, Palaeoclimatology, Palaeoecology, 220, 69-88.

- KRASSIlOV, V. A., LEgUTA, A. V., MELNIKOVA, L. M., URBANEK, A., USHATINSKAYA, G. T. and MALAKHOVSKAYA, Y. E. 2005b. Unique Sinsk localities of Early Cambrian organisms. Transactions of the Palaeontological Institute, 284, 1-143.

JACHOWICZ, M. and MORYC, W. 1995. Cambrian platform deposits in boreholes Rajbrot 1 and Rajbrot 2 south of Bochnia (southern Poland). Przeglad Geologiczny, 43, 935. 
JENSEN, S. 1990. Predation by early Cambrian trilobites on infaunal worms - evidence from the Swedish Mickwitzia Sandstone. Lethaia, 23, 29-42.

1997. Trace fossils from the Lower Cambrian Mickwitzia sandstone, south-central Sweden. Fossils \& Strata, 42, 1-112.

— and BERGSTRÖM, J. 1995. The trace fossil Fucoides circinatus Brongniart, 1828, from its type area, Västergötland, Sweden. GFF, 117, 207-210.

2000. Cheiichnus gothicus igen. et isp. n., a new Bergaueria-like arthropod trace fossil from the Lower Cambrian of Västergötland, Sweden. GFF, 122, 293-296.

KIRSCHVINK, J. L., RIPPERDAN, R. L. and EVANS, D. A. 1997. Evidence for a large-scale reorganization of Early Cambrian continental masses by inertial interchange true polar wander. Science, 277, 541-545.

KIRYANOV, V. V. 1979. Rastitelnye mikrofossilii (Plant microfossils). 4-38. In VOLKOVA, N. A., KIRYANOV, V. V., PISKUN, L. V., PASKEVICIENE, L. T. and YANKAUKAS, T. V. (eds). Paleontologiya Verkhnedokembriiskikh i Kembriiskikh otlozhenii Vostochno-Evropeiskoi Platformy. (Upper Precambrian and Cambrian palaeontology of the east European Platform). Akademiya Nauk SSSR, Ordena Trudovogo Krasnogo Znameni Geologicheskii Institut, Izdatelstvo Nauka, Moscow. [English translation, 1983. Wydawnictwa Geologiczne, Warsaw, pp. 7-47]

KNIGHT-JONES, P. 1981. Behaviour, setal inversion and phylogeny of Sabellida (Polychaeta). Zoologica Scripta, 10, 183-202.

KONZALOVÁ, O. F.-M. 1995. Microfossils of the Paseky Shale (Lower Cambrian, Czech Republic). Journal of the Czech Geological Society, 40, 55-66.

KRUMBIEGEL, G., DEICHFUSS, H. and DEICHFUSS, H. 1980. Ein neuer fund von Xenusion. Hallesches Jahrbuch für Geowissenschaften, 5, 97-99.

LAMARCK, J.-B.-P. 1809. Philosophie zoologique. 484 pp.

LAND, J. VAN DER 1970. Systematics, zoogeography, and ecology of the Priapulida. Zoologische Verhandelingen, 112, 1118.

LANDING, E., GEYER, G., BRASIER, M. D. and BOWRING, S. A. 2013. Cambrian evolutionary radiation: context, correlation, and chronostratigraphy-overcoming deficiencies of the first appearance datum (FAD) concept. Earth-Science Reviews, 123, 133-172.

LENDZION, K. 1975. Fauna of the Mobergella zone in the Polish Lower Cambrian. Geological Quarterly, 19, 237-242.

LI, Z.-X., BOGdanOVA, S. V., COllins, A. S., DAVIDSON, A., DE WAELE, B., ERNST, R. E., FITZSIMONS, I. C. W., FUCK, R. A., GLADKOCHUB, D. P. and JACOBS, J. 2008. Assembly, configuration, and break-up history of Rodinia: a synthesis. Precambrian Research, 160, 179-210.

LIDMAR-BERGSTRÖM, K. 1988. Denudation surfaces of a shield area in south Sweden. Geografiska Annaler, Series A, 70 337-350.

LINNARSSON, J. G. O. 1871. Geognostiska och paleontologiska iakttagelser öfver Eophytonsandstenen i Vestergötland. Kongliga Svenska Vetenskaps-Akademiens Handlingar, 9, 19 pp.
LIU, Y., XIAO, S., SHAO, T., BROCE, J. and ZHANG, H. 2014. The oldest known priapulid-like scalidophoran animal and its implications for the early evolution of cycloneuralians and ecdysozoans. Evolution \& Development, 16, 155165.

LIU, J., OU, Q., HAN, J., LI, J., WU, Y., JIAO, G. and HE, T. 2015. Lower Cambrian polychaete from China sheds light on early annelid evolution. The Science of Nature, 102, 34.

McILROY, D. 2004. The application of ichnology to palaeoenvironmental and stratigraphic analysis: introduction. Geological Society, London, Special Publications, 228, 1-2.

McKERROW, W. S., SCOTESE, C. R. and BRASIER, M. D. 1992. Early Cambrian continental reconstructions. Journal of the Geological Society, 149, 599-606.

MEERT, J. G. 2014. Ediacaran-Early Ordovician paleomagnetism of Baltica: a review. Gondwana Research, 25, 159-169.

_ and LIEBERMAN, B. S. 2004. A palaeomagnetic and palaeobiogeographical perspective on latest Neoproterozoic and early Cambrian tectonic events. Journal of the Geological Society, 161, 477-487.

_ 2008. The Neoproterozoic assembly of Gondwana and its relationship to the Ediacaran-Cambrian radiation. Gondwana Research, 14, 5-21.

MERZ, R. A. and WOODIN, S. A. 2006. Polychaete chaetae: function, fossils, and phylogeny. Integrative \& Comparative Biology, 46, 481-496.

METTAM, C. 1971. Functional design and evolution of the polychaete Aphrodite aculeata. Journal of Zoology, 163, 489514.

— 1984. Functional morphology of locomotion in Chloeia (Polychaeta; Amphinomidae). 390-400. In HUTCHINGS, P. A. (ed.) Proceedings of the First International Polychaete Conference. Linnean Society of New South Wales.

MISSARZHEVSKY, V. V. 1973. Conodont-like organisms from boundary layers of Cambrian and Precambrian in the Siberian platform and Kazakhstan. 53-57. In Problems in paleontology and biostratigraphy of the Lower Cambrian of Siberia and the Russian Far East. Nauka, Novosibirsk. [in Russian]

MOCZYDŁ OWSKA, M. 1991. Acritarch biostratigraphy of the Lower Cambrian and the Precambrian-Cambrian boundary in southeastern Poland. Fossils \& Strata, 29, 127 pp.

1998. Cambrian acritarchs from Upper Silesia, Poland: biochronology and tectonic implications. Fossils \& Strata, 46, $121 \mathrm{pp}$.

— 2008. New records of late Ediacaran microbiota from Poland. Precambrian Research, 167, 71-92.

_ and VIDAL, G. 1986. Lower Cambrian acritarch zonation in southern Scandinavia and southeastern Poland. Geologiska Föreningen i Stockholm Förhandlingar, 108, 201-223.

NAGOVITSIN, K. E., 2011. Macrofossils and microfossils in the Kessyusa Formation from boreholes drilled in the Molodo river area (Arctic region, Siberian Craton). 63-64 In GRAZHDANKIN, D. V. and MARUSIN, V. V. (eds). Neoproterozoic sedimentary basins: stratigraphy, geodynamics and petroleum potential. Trofimuk Institute of Petroleum Geology and Geophysics, Siberian Branch of the Russian Academy of Sciences. 
NIELSEN, A. T. and SCHOVSBO, N. H. 2007. Cambrian to basal Ordovician lithostratigraphy in southern Scandinavia. Bulletin of the Geological Society of Denmark, 53, 47-92.

_ _ 2011. The Lower Cambrian of Scandinavia: depositional environment, sequence stratigraphy and palaeogeography. Earth-Science Reviews, 107, 207-310.

2015. The regressive Early-Mid Cambrian 'Hawke Bay Event' in Baltoscandia: Epeirogenic uplift in concert with eustasy. Earth-Science Reviews, 151, 288-350.

O' CLAIR, R. M. and CLONEY, R. A. 1974. Patterns of morphogenesis mediated by dynamic microvilli: chaetogenesis in Nereis vexillosa. Cell \& Tissue Research, 151, 141-157.

ORŁ OWSKI, S. and ŻYLIŃSKA, A. 1996. Non-arthropod burrows from the Middle and Late Cambrian of the Holy Cross Mountains, Poland. Acta Palaeontologica Polonica, 41, 385-409.

ORR, P. J., BENTON, M. J. and BRIGGS, D. E. G. 2003. Post-Cambrian closure of the deep-water slope-basin taphonomic window. Geology, 31, 769-772.

PALACIOS, T., JENSEN, S., BARR, S. M., WHITE, C. E. and MILLER, R. F. 2011. New biostratigraphical constraints on the lower Cambrian Ratcliffe Brook Formation, southern New Brunswick, Canada, from organic-walled microfossils. Stratigraphy, 8, 45.

— SÁNCHEZ, I. C. and MUS, M. M., 2014. First Lower Cambrian record of Wiwaxia from north-west Gondwana: small carbonaceous fossils from the Lancara Formation, Cantabrian Mountains, northern Spain. The Palaeontological Association 58th Annual Meeting, Programme Abstracts and AGM papers, p. 90.

PARRY, L., TANNER, A. and VINTHER, J. 2014. The origin of annelids. Palaeontology, 57, 1091-1103.

— Vinther, J. and EDGECOMBE, G. D. 2015. Cambrian stem-group annelids and a metameric origin of the annelid head. Biology Letters, 11, 20150763.

- EDGeCOMBE, G. D., EIBYE-JACOBSEN, D. and VINTHER, J. 2016. The impact of fossil data on annelid phylogeny inferred from discrete morphological characters. Proceedings of the Royal Society B, 283, 20161378.

PATERSON, J. R., GARCÍA-BELLIDO, D. C., JAGO, J. B., GEHLinG, J. G., LEE, M. S. and EDGECOMBE, G. D. 2016. The Emu Bay Shale Konservat-Lagerstätte: a view of Cambrian life from East Gondwana. Journal of the Geological Society, 173, 1-11.

PIŽL, V. and CHALUPSKÝ, J. 1984. Hrabeiella periglandulata gen. et sp. n. (Annelida): a curious worm from Czechoslovakia. Acta Societatis Zoologicae Bohemoslovenicae, 48, 291-295.

PORTER, S. M. 2004. Halkieriids in Middle Cambrian phosphatic limestones from Australia. Journal of Paleontology, 78, 574-590.

POSSAMENTIER, H. W. and ALLEN, G. P. 1999. Siliciclastic sequence stratigraphy - concepts and applications. SEPM. Concepts in Sedimentology \& Palaeontology, 7.

PURSCHKE, G. 2002. On the ground pattern of Annelida. Organisms Diversity and Evolution, 2, 181-196.

PYLE, L. J., NARBONNE, G. M., NOWLAN, G. S., XIAO, S. and JAMES, N. P. 2006. Early Cambrian metazoan eggs, embryos, and phosphatic microfossils from northwestern Canada. Journal of Paleontology, 80, 811-825.
RIEDMAN, L. A., PORTER, S. M., HALVERSON, G. P., HURTGEN, M. T. and JUNIUM, C. K. 2014. Organic-walled microfossil assemblages from glacial and interglacial Neoproterozoic units of Australia and Svalbard. Geology, 42, 1011-1014.

ROTA, E. and LUPETTI, P. 1996. An ultrastructural investigation of Hrabeiella Pižl and Chalupský, 1984 (Annelida). I. Chaetae and body wall organization. 229-239. In COATES, K. A., REYNOLDSON, T. B. and REYNOLDSON, T. B. (eds). Aquatic oligochaete biology VI. Springer.

ROUSE, G. and PLEIJEL, F. 2001. Polychaetes. Oxford University Press, $354 \mathrm{pp}$.

ROY, P. A. 1974. Tube dwelling behavior in the marine annelid Phragmatopoma californica (Fewkes) (Polychaeta: Sabellariidae). Bulletin of the Southern California Academy of Sciences, 73, 117-125.

RYDELL, J., HAMMARLUND, J. and SEILACHER, A. 2001. Trace fossil associations in the Swedish Mickwitzia sandstone (Lower Cambrian): did trilobites really hunt for worms? GFF, 123, 247-250.

SAMSON, S., PALMER, A. R., ROBISON, R. A. and SECOR, D. T. 1990. Biogeographical significance of Cambrian trilobites from the Carolina slate belt. Geological Society of America Bulletin, 102, 1459-1470.

SCHMIDT-RHAESA, A. 2013. Priapulida. 147-180. In SCHMIDT-RHAESA, A. (ed.) Handbook of Zoology: Gastrotricha, Cycloneuralia and Gnathifera. Vol. 1. De Gruyter.

SCHROEDER, P. G. 1984. Chaetae. 297-309. In BEREITER-HAHN, P. D. J., MATOLTSY, P. D. A. G. and RICHARDS, D. K. S. (eds). Biology of the integument. Springer.

SHAO, T.-Q., LIU, Y.-H., WANG, Q., ZHANG, H.-Q., TANG, H.-H. and LI, Y. 2016. New material of the oldest known scalidophoran animal Eopriapulites sphinx. Palaeoworld, 25, $1-11$.

SKOVSTED, C. B. and PEEL, J. S. 2007. Small shelly fossils from the argillaceous facies of the Lower Cambrian Forteau formation of western Newfoundland. Acta Palaeontologica Polonica, 52, 729-748.

SMITH, M. R. 2014. Ontogeny, morphology and taxonomy of the soft-bodied Cambrian 'mollusc' Wiwaxia. Palaeontology, 57, 215-229.

- 2015. A palaeoscolecid worm from the Burgess Shale. Palaeontology, 58, 973-979.

— HUGHES, G. M. G., VARGAS, M. C. and PARRA, F. DE LA 2015a. Sclerites and possible mouthparts of Wiwaxia from the temperate palaeolatitudes of Colombia, South America. Lethaia, 49, 393-397.

HARVEY, T. H. P. and BUtTeRfield, N. J. $2015 b$. The macro- and microfossil record of the Cambrian priapulid Ottoia. Palaeontology, 58, 705-721.

SOUTHGATE, P. N. and SHERGOLD, J. H. 1991. Application of sequence stratigraphic concepts to Middle Cambrian phosphogenesis, Georgina Basin, Australia. Journal of Australian Geology \& Geophysics, 12, 119-144.

STEINER, M. and FATKA, O. 1996. Lower Cambrian tubular micro- to macrofossils from the Paseky Shale of the Barrandian area (Czech Republic). Paläontologische Zeitschrift, 70, 275-299. 
STØRMER, L. 1956. A Lower Cambrian merostome from Sweden. Arkiv för Zologi, 9, 507-514.

STRENG, M., EBBESTAD, J. O. R. and BERG-MADSEN, V. 2016. Cambrian palaeoscolecids (Cycloneuralia) of southern Scandinavia. Papers in Palaeontology, published online 15 October. doi: 10.1002/spp2.1067

STRUCK, T. H., PAUL, C., HILL, N., HARTMANN, S., HÖSEL, C., KUBE, M., LIEB, B., MEYER, A., TIEDEMANN, R., PURSCHKE, G. and BLEIDORN, C. 2011. Phylogenomic analyses unravel annelid evolution. Nature, 471, 95-98.

THORSLUnD, P. and WESTERGÅR, A. H. 1938. Deep boring through the Cambro-Silurian at File Haidar, Gotland. Sveriges Geologiska Undersoking, Series C, 415, 1-57.

Tilic, E., BARTOlomaeus, T. and ROUSE, G. W. 2015a. Chaetal type diversity increases during evolution of Eunicida (Annelida). Organisms Diversity \& Evolution, 16, $105-119$.

_ LEHRKe, J. and BARTOlomaeus, T. $2015 b$. Homology and evolution of the Chaetae in Echiura (Annelida). PLoS One, 10, e0120002.

TOPPER, T. P. and SKOVSTED, C. B. 2014. A new name for a classic Cambrian Swedish brachiopod, Tallatella undosa (Moberg). GFF, 136, 429-435.

- BROCK, G. A., SKOVSTED, C. B. and PATERSON, J. R. 2009. Shelly fossils from the Lower Cambrian 'Pararaia bunyerooensis' Zone, flinders ranges, South Australia. Australasian Palaeontological Memoirs, 199.

$-\_-2010$. Palaeoscolecid scleritome fragments with Hadimopanella plates from the early Cambrian of South Australia. Geological Magazine 147, 86-97.

- Strotz, L. C., HOLMER, L. E., ZHANG, Z., TAIT, N. N. and CARON, J.-B. 2015. Competition and mimicry: the curious case of chaetae in brachiopods from the middle Cambrian Burgess Shale. BMC Evolutionary Biology, 15, 42.

TORSVIK, T. H. and COCKS, L. R. M. 2005. Norway in space and time: a centennial cavalcade. Norwegian Journal of Geology, 85, 73-86.

_ 2013. Gondwana from top to base in space and time. Gondwana Research, 24, 999-1030.

— and REHNSTRÖM, E. F. 2001. Cambrian palaeomagnetic data from Baltica: implications for true polar wander and Cambrian palaeogeography. Journal of the Geological Society, 158, 321-329.

URBANEK, A. and ROZANOV, A. U. 1983. Upper Precambrian and Cambrian palaeontology of the East-European platform. Wydawnictwa Geologiczne, Warsaw, $157 \mathrm{p}$.

VANNIER, J. 2012. Gut contents as direct indicators for trophic relationships in the Cambrian marine ecosystem. PLoS One, 7, e52200.
VIDAL, G. 1981. Lower Cambrian acritarch stratigraphy in Scandinavia. Geologiska Föreningen i Stockholm Förhandlingar, 103, 183-192.

WALCOTT, C. D. 1911. Middle Cambrian annelids. Smithsonian Miscellaneous Collections, 57, 109-144.

WELIN, E., LINDH, A. and KÄHR, A.-M. 1982. The radiometric age of the Proterozoic granite at Sandsjön, western Värmland, Sweden. Geologiska Föreningen i Stockholm Förhandlingar, 103, 514-518.

WENNBERG, S. A., JANSSEN, R. and BUDD, G. E. 2009. Hatching and earliest larval stages of the priapulid worm Priapulus caudatus. Invertebrate Biology, 128, 157-171.

WILlS, M. A., GERBER, S., RUTA, M. and HUGHES, M. 2012. The disparity of priapulid, archaeopriapulid and palaeoscolecid worms in the light of new data. Journal of Evolutionary Biology, 25, 2056-2076.

WRight, A. E., FAIRCHILD, I. J., MOSELEY, F. and DOWNIE, C. 1993. The Lower Cambrian Wrekin Quartzite and the age of its unconformity on the Ercall Granophyre. Geological Magazine, 130, 257-264.

YANG, J., SMITH, M. R., LAN, T., HOU, J.-B. and ZHANG, X.-G. 2014. Articulated Wiwaxia from the Cambrian Stage 3 Xiaoshiba Lagerstätte. Scientific Reports, 4, 4643.

ZANG, W., MOCZYDŁOWSKA, M. and JAGO, J. B. 2007. Early Cambrian acritarch assemblage zones in South Australia and global correlation. Australasian Palaeontological Memoirs, 141.

ZHANG, Z. and HOLMER, L. E. 2013. Exceptionally preserved brachiopods from the Chengjiang Lagerstätte (Yunnan, China): perspectives on the Cambrian explosion of metazoans. Science Foundation in China, 21, 66-80.

ZHANG, X.-G., HOU, X.-G. and BERGSTRÖM, J. 2006. Early Cambrian priapulid worms buried with their lined burrows. Geological Magazine, 143, 743-748.

ZHANG, Z., SHU, D., HAN, J. and LIU, J. 2007. A gregarious lingulid brachiopod Longtancunella chengjiangensis from the Lower Cambrian, South China. Lethaia, 40, 11-18.

ZHANG, H., XIAO, S., LIU, Y., YUAN, X., WAN, B., MUSCENTE, A. D., SHAO, T., GONG, H. and CAO, G. 2015a. Armored kinorhynch-like scalidophoran animals from the early Cambrian. Scientific Reports, 5, 16521.

ZHANG, Z., SMITH, M. R. and SHU, D. 2015b. New reconstruction of the Wiwaxia scleritome, with data from Chengjiang juveniles. Scientific Reports, 5, 14810.

ZHAO, Y.-L., QIAN, Y. and LI, X.-S. 1994. Wiwaxia from Early-Middle Cambrian Kaili Formation in Taijiang, Guizhou. Acta Palaeontologica Sinica, 33, 359-366.

ZHAO, F.-C., SMITH, M. R., YIN, Z.-J., ZENG, H., HU, S.-X., LI, G.-X. and ZHU, M.-Y. 2015. First report of Wiwaxia from the Cambrian Chengjiang Lagerstätte. Geological Magazine, 152, 378-382. 